\title{
PRAVNO UREĐENJE KVALIFIKACIJA ZA PARTICIPACIJU GRAĐANA LAIKA U SUĐENJU U HRVATSKOJ OD 1848. DO 2018.
}

Sažetak: $\quad$ Polazeći od toga da se sudjelovanje građana u postupku donošenja odluka ne oživotvoruje samo u zakonodavnoj i izvršnoj, nego i sudbenoj vlasti, u radu se pobliže razmatraju kvalifikacije građana laika za njihovu participaciju u suđenju. Propisivanjem pojedinih kvalifikacija, a napose njihova povećeg broja, značajno se može utjecati na mogućnost participacije građana laika u suđenju, ograničavajući broj onih koji tim uvjetima mogu udovoljiti i istovremeno smanjujući mogućnost ostvarivanja važnih uloga participacije koje ne sadrže samo vitalni imperativ suvremene ustavno-demokratske države za demokratizacijom pravosuđa, nego i važnu edukativnu i integrativnu komponentu. Uvažavajući okolnost da su u pojedinim razdobljima hrvatske povijesti građani laici sudjelovali najprije u porotnom, a zatim u prisjedničkom suđenju, u nastojanju za cjelovitim $i$ sustavnim pristupom ovoj materiji $u$ radu se razmatraju relevantni propisi $i$ dostupna literatura o načinu pravnog uređenja kvalifikacija građana laika $u$ suđenju u razdoblju od 1848. do 2018. radi istraživanja mogućeg utjecaja ranijih zakonskih rješenja na oblikovanje važećih odredbi kojima se uređuje ta materija, ali i postojanja prostora za eventualno unaprjeđenje nekih od važećih rješenja.

Ključne riječi: $\quad$ participacija, građani laici, prisjedničko suđenje, porotno suđenje

\section{UVOD}

U nastojanju za stvaranjem poticajnog okruženja za participaciju (sudjelovanje) građana u postupcima donošenja odluka, u proteklom desetljeću doneseno je nekoliko važnih zakona,

Gordan Struić, mag. iur. univ. spec. pol. Hrvatski sabor, Trg sv. Marka 6, 10000 Zagreb, Republika Hrvatska. Adresa e-pošte: gordan.struic@gmail.com. ORCID: http://orcid.org/0000-0001-6528-4436. U radu su izneseni osobni stavovi autora. 
drugih propisa i dokumenata. ${ }^{1}$ Sudjelovanje građana u postupku donošenja odluka ne oživotvoruje se samo u zakonodavnoj i izvršnoj, ${ }^{2}$ nego i u sudbenoj vlasti, kroz sudjelovanje građana laika (laika u pravu) u suđenju, a dva temeljna oblika navedene participacije predstavljaju porotni i prisjednički (tzv. mješoviti) sud. ${ }^{3}$ Porotni sud sastavljen je od dva dijela: porote, koju čini određeni broj porotnika, tj. građana laika kao privremenih, neprofesionalnih sudaca i jednog ili više sudaca kao stalnih, profesionalnih sudaca, pri čemu o svim činjeničnim pitanjima, odnosno krivnji optuženika odlučuje porota, dok o svim pravnim pitanjima, odnosno kazni odlučuje profesionalni sudac. Prisjednički sud predstavlja jedinstveno tijelo (sudsko vijeće) sastavljeno od određenog broja građana laika kao privremenih, neprofesionalnih sudaca i jednog ili više sudaca kao stalnih, profesionalnih sudaca, pri čemu svi članovi sudskog vijeća ravnopravno odlučuju o pravnim i činjeničnim pitanjima, odnosno o krivnji i kazni. ${ }^{4}$

Korijene participacije građana laika u suđenju valjalo bi primijetiti u antičkoj demokraciji i ulozi narodnih sudova, kada je suđenje bilo stavljano u ruke gotovo cijelog naroda, odnosno jednoga njegova velikog dijela koji je mogao odlučivati i, pritom, suočiti se s "odgovornošću čije posljedice mogu uništiti ne samo nečiju čast ili imovinu nego i cijelu obitelj i naposljetku

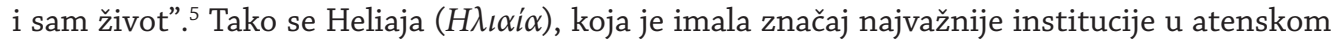
sudskom sustavu, sastojala od ukupno 6.000 građana pa se ističe da su pravdu dijelili i odluke donosili "svi atenski građani iznad 30 godina starosti”. ${ }^{6} \mathrm{U}$ antičkom Rimu građani laici također su sudjelovali u suđenju, najprije kroz djelovanje narodnih skupština (comitia), a od 2. stoljeća pr. n. e. i kroz djelovanje stalnih sudova (quaestiones perpetuae) koji su se sastojali od 70, 75, 80 i 100 građana laika ${ }^{7}$ pod predsjedanjem posebnog magistrata ili pretora (praetor de repetundis), ${ }^{8}$ s time da su se na listi građana laika, tzv. prisežnika (album iudicum) mogli naći rimski građani koji su imali od 30 do 60 godina, ${ }^{9}$ uz nekoliko dodatnih uvjeta, poput imovinskog

1 Npr. Kodeks savjetovanja sa zainteresiranom javnošću u postupcima donošenja zakona, drugih propisa i akata (Narodne novine, broj 140/2009), Zakon o procjeni učinaka propisa (Narodne novine, broj 44/2017), Zakon o pravu na pristup informacijama (Narodne novine, broj 25/2013, 85/2015) itd. Vidi npr.: Struić, G.; Bratić, V., Sudjelovanje javnosti u zakonodavnom postupku: primjer Odbora za financije i državni proračun Hrvatskoga sabora, Hrvatska i komparativna javna uprava, god. 17, br. 1, 2017.

2 O participaciji u zakonodavnoj vlasti vidi npr.: Struić, G.; Bratić, V., Public participation in the budgetary process in the Republic of Croatia, Public Sector Economics, god. 42, br. 1, 2018., str. 67.-92. O participaciji u izvršnoj vlasti vidi npr.: Vidačak, I.; Đurman, P., Savjetovanje s javnošću u donošenju propisa: kvaliteta javnog odlučivanja i sudjelovanje građana, u: I. Koprić; A. Musa; T. Giljević, (ur.), Građani, javna uprava, lokalna samouprava: povjerenje, suradnja, potpora, Institut za javnu upravu, Zagreb, 2017., str. 73.-104. O participaciji u lokalnoj samoupravi vidi npr.: Koprić, I.; Manojlović, R., Participacija građana u lokalnoj samoupravi nova hrvatska pravna regulacija i neka komparativna iskustva, u: B. Davitkovski (ur.), Četvrti Skopsko-zagrebački pravni kolokvij, Pravni fakultet, Skopje, 2013., str. 9.-35.

3 Pored tih temeljnih oblika participacije postoje i neke njihove varijacije. Vidi npr.: Machura, S., Civil Justice: Lay Judges in the EU Countries, Onati Socio-legal Series, god. 6, br. 2, 2016.; Leib, E. J., A Comparison of Criminal Jury Decision Rules in Democratic Countries, Ohio State Journal of Criminal Law, god. 5, 2008.; Kużelewski, D., The Election of Lay Judges and the Principle of Participation by Citizenry in the Administration of Criminal Justice, Białostockie Studia Prawnicze, god. 20/A, 2016.

4 Krapac, D.; Đurđević, Z.; Ivičević Karas, E.; Bonačić, M.; Burić, Z., Kazneno procesno pravo, Prva knjiga: Institucije, Narodne novine, Zagreb, 2015., str. 147.-148.

5 Erent-Sunko, Z., Atenske demokratske institucije i njihov odraz na socijalne pojave (6.-4. st. pr. n. e.), Pravni fakultet Sveučilišta u Zagrebu, Zagreb, 2007., str. 103.-104.

6 Ibid., str. 103.; MacKercher, J., Trial by jury, [s. n.], Montreal, 1891., str. 4.

7 Horvat, M., Rimsko pravo, Pravni fakultet Sveučilišta u Zagrebu, Zagreb, 2007., str. 57.

8 Chroust, A.-H.; Murphy, J. R., Lex Acilia and the Rise of Trial by Jury in the Roman World, Notre Dame Law Review, god. 24, br. 1, 1948., str. 1.-2.

9 Minimalna dob za građane laike koji su tako mogli sudjelovati u suđenju postupno se smanjivala, i to najprije s 30 na 25 , a zatim i na 20 godina. MacKercher, op. cit. u bilj. 6, str. 5 . 
cenzusa, neosuđivanosti itd. ${ }^{10}$ Iako ne postoje posve jasni povijesni izvori, u skandinavskim zemljama građani laici mogli su sudjelovati u suđenju od 9. stoljeća. ${ }^{11}$ U Norveškoj je tako postojalo sudbeno tijelo Laugrettomadr, sastavljeno od predsjedatelja s pravnim znanjem (logmann) i 36 građana laika, koje je odlučivalo o pravnim i činjeničnim pitanjima, slično kao i u Švedskoj Nämbd, tijelo sastavljeno od dvanaest građana laika koji su bili "pravi muškarci (...), nisu stranke u predmetu, niti njihovi prijatelji ili rodbina", ${ }^{12}$ odnosno u Danskoj Ncevninger, s dvanaest, a u nekim slučajevima i više članova. ${ }^{13}$ Slično tijelo može se pronaći i na Islandu, gdje je prije prihvaćanja kršćanstva (na prijelazu iz 10. u 11. stoljeće) bio ustanovljen Tolftar-Quidr koji je činilo dvanaest članova, od kojih je jedan bio magistrat, dok su njih jedanaest bili građani laici koji su morali imati najmanje 20 godina, nisu smjeli biti u srodstvu s nekom od stranaka u sporu, nisu smjeli biti bolesni, nemoćni i osuđeni, niti imati interes u predmetu koji se vodi pred tim tijelom te su morali ispuniti i uvjete imovinskog cenzusa i blizine lokaciji u vezi sa spornim pitanjem. ${ }^{14}$

Spomenuti primjeri svjedoče o povijesnoj ukorijenjenosti participacije građana laika u suđenju, no istovremeno se iz njih može i razabrati da se oživotvorenje participacije još u starom i srednjem vijeku vezivalo uz određene uvjete, kao što se uz njih veže i danas. U pravilu, riječ je o uvjetima koji predstavljaju minimalne kvalifikacije poput određene dobi (minimalne, a ponegdje i maksimalne) i državljanstva, no uz njih je moguće propisati i neke druge kvalifikacije, poput stručnosti i iskustva, ali i dostojnosti i sličnih etičkih kategorija. Nadalje, riječ je i o uvjetima koji se odnose na isključenje, poput inkompatibilnosti s nekim drugim dužnostima (zastupničkom, odvjetničkom, javnobilježničkom ili drugom dužnošću), odnosno poslovima i službama koje mogu utjecati na samostalnost, nepristranost ili neovisnost. S druge strane, propisivanje pojedinih uvjeta, a napose njihova povećeg broja, značajno bi moglo utjecati na mogućnost participacije pojedinih skupina građana laika u suđenju, ograničavajući broj onih koji tim uvjetima mogu udovoljiti i usto smanjujući mogućnost ostvarivanja uloga participacije u društveno-pravnom životu.

Iako je u literaturi zamijećen niz radova na temu participacije građana laika u suđenju - od kojih se popriličan broj bavi porotnim sudom, ${ }^{15}$ dok se prisjedničkom sudu posvećivalo nešto više pažnje tek u posljednjih dvadesetak godina, posebice na engleskom jeziku ${ }^{16}$ - pitanju kva-

10 Vidi: Bablitz, L., Actors and Audience in the Roman Courtroom, Routledge, Abingdon-New York, 2007., str. 92.

11 Repp, T. G., A historical treatise on trial by jury, wager of law, and other co-ordinate forensic institutions, formerly in use in Scandinavia and Iceland, Saunders and Benning, London, 1832., str. 5.

12 Forsyth, W., History of trial by jury, R. Carswell, Toronto, 1876., str. 21.

13 Proffatt, J., Treatise on Trial by Jury: Including Question of Law and Fact With an Introductory Chapter on the Origin and History of Jury Trial, Sumner Whitney and Company, San Francisco, 1880., str. 12.

Repp, op. cit. u bilj. 11, str. 182.-186.

15 Npr.: Hans, V. P., American Juries: The Verdict, Prometheus Books, New York, 2007.; Jonakait, R. N., The American jury system, Yale University Press, New Haven, 2003.; Vidmar, N. (ur.), World Jury Systems, Oxford University Press, New York, 2000.; Vidmar, N.; Abbott, W. F.; Batt, J. (ur.), A handbook of jury research, American Law Institute-American Bar Association, Philadelphia, 1999. Od radova u hrvatskoj literaturi vidi npr.: Čepulo, D., Sloboda tiska i porotno suđenje u banskoj Hrvatskoj 1848-1918., Hrvatski ljetopis za kazneno pravo i praksu, god. 7, br. 2, 2000.; Pastović, D., Analiza prakse porotnog suda u Rovinju 1874.-1918., Zagrebačka pravna revija, god. 4, br. 1, 2015. i druge radove koji se u tom kontekstu navode u ovom radu.

16 Npr.: Kutnjak Ivković, S., Exploring Lay Participation in Legal Decision-Making: Lessons from Mixed Tribunals, Cornell International Law Journal, god. 40, br. 2, 2007.; Machura, S., Interaction between lay assessors and professional judges in German mixed courts, Revue internationale de droit pénal, god. 72, br. 1-2, 2001.; Casper, G.; Zeisel, H., Lay judges in the German criminal courts, The Journal of Legal Studies, god. 1, br. 1, 1972. Od hrvatske literature vidi npr.: Bayer, V., Problem sudjelovanja nepravnika u savremenom kaznenom sudovanju, Tiskara Merkantile (Jutriša i Sedmak), Zagreb, 1940.; Pavičić, A., Sudjelovanje sudaca porotnika 
lifikacija, tj. uvjeta pod kojima građani laici mogu participirati u suđenju dosad se u literaturi nije pridavala dovoljno velika istraživačka pozornost. Imajući to u vidu, a napose s obzirom na to da na temelju članka 121. stavka 2. Ustava Republike Hrvatske ${ }^{17}$ u suđenju sudjeluju i suci porotnici, ${ }^{18} \mathrm{u}$ ovom radu pobliže se prati način pravnog uređenja kvalifikacija građana laika za njihovu participaciju u suđenju u Hrvatskoj u razdoblju od punih 170 godina - od 1848. do 2018. - kako bi se istražilo mogući utjecaj ranijih zakonskih rješenja na oblikovanje važećih odredbi koje uređuju tu materiju, ali i postojanje prostora za eventualno unaprjeđenje pojedinih važećih rješenja. U tom cilju, u radu se analiziraju relevantne odredbe niza propisa kojima je (bila) uređena ova materija, uz korištenje dostupne literature pri osvrtu na pojedina normativna rješenja. Pri postavljanju vremenskog okvira nastojalo se uvažiti okolnost da su u pojedinim razdobljima hrvatske povijesti građani laici mogli sudjelovati (najprije) u porotnom i (zatim u) prisjedničkom suđenju.

Stoga, nakon prvoga, uvodnog dijela rada, u drugom dijelu najprije se općenito razmatraju uloge participacije građana laika u suđenju, dok se u trećem dijelu rada ukratko prikazuje razdoblje porotnog suđenja u Hrvatskoj i način pravnog uređenja kvalifikacija koje su građani laici u tom razdoblju morali ispunjavati kako bi u svojstvu porotnika mogli sudjelovati u suđenju. Nakon što se u četvrtom dijelu prikaže razdoblje prisjedničkog suđenja u Hrvatskoj i razmotri način pravnog uređenja kvalifikacija za suce porotnike u tom razdoblju, sve do važećih normativnih rješenja, u petom dijelu razmatraju se mogućnosti unaprjeđenja važećih rješenja, dok se u šestom, završnom dijelu ovog rada pristupa zaključnim razmatranjima.

\section{ULOGE PARTICIPACIJE GRAĐANA LAIKA U SUĐENJU}

Participaciji građana u postupcima donošenja odluka općenito se pripisuje nekoliko uloga. Pojedini autori participaciji građana pripisuju instrumentalnu ulogu ${ }^{19}$ svodeći je - napose onda kada je riječ o donošenju političkih odluka - isključivo na izbor vladajuće strukture i smatrajući da se za nju, u pravilu, odlučuje "glasna manjina, kojoj se ne može povjeriti da nas sve predstavlja”. ${ }^{20}$ Također, pojedini autori ističu da se participacija temelji na odveć optimi-

u kaznenim postupcima pred Županijskim sudom u Zagrebu, Hrvatski ljetopis za kazneno pravo i praksu, god. 12, br. 1, 2005. i druge radove koji se u tom kontekstu navode u ovom radu.

17 Narodne novine, broj 56/1990, 135/1997, 8/1998, 113/2000, 124/2000, 28/2001, 41/2001, 55/2001, 76/2010, 85/2010, $5 / 2014$.

18 Iako se u hrvatskoj ustavnoj i zakonskoj terminologiji koristi pojam sudaca porotnika kako bi se pod njim označilo građane laike koji kao privremeni, neprofesionalni suci, zajedno s jednim ili više sudaca kao stalnih, profesionalnih sudaca, imaju pravo ravnopravno odlučivati o pravnim i činjeničnim pitanjima, odnosno o krivnji i kazni u okviru prisjedničkog suda, riječ je o neodgovarajućem pojmu umjesto kojeg bi primjerenije bilo koristiti pojam prisjednika radi jasnijeg razlikovanja od porotnika kao građana laika koji sudjeluju u porotničkom suđenju. U tom smislu, vidi npr. Bayer, op. cit. u bilj. 16, str. 2.-3. U potrazi za mogućim razlozima korištenja pojma sudaca porotnika valjalo bi podcrtati shvaćanje istog autora o namjeri da se uvedu prisjednički sudovi, ali zadrži "onaj ugled, koji je (...) uživao porotni sud” (Ibid., str. 3.), a jedan od mogućih normativnih uzora za korištenje tog pojma mogao bi biti Zakon o poroti iz 1871. (Srpske novine, broj 134/1871) kojim je bilo predviđeno da porotnik može biti svaki srpski građanin s navršenih 30 godina u trenutku izbora porotnika, uz još dva uvjeta: da je prije toga "stalno živio" u Srbiji najmanje pet godina i da plaća "najmanje šest talira godišnje redovnog državnog danka" (članak 1.). 
stičnoj slici građana koji želi najbolje svojoj zajednici i koji se može obrazovati radi djelovanja "u korist općeg dobra", ${ }^{21}$ dok je njihova stvarna slika počesto drugačija, otkrivajući kako se ubrzo aktivni građanin usmjeren na javno dobro može pretvoriti u pasivnog pojedinca koji je “zaokupljen svojim privatnim prilikama i strahovima”.22 Stoga, polazeći od relativne naravi njezine zbiljske uloge, spram one idealne koja počiva na nekritičkom optimizmu, doima se da je jedno od ključnih pitanja, odnosno prijepora u vezi s participacijom građana u postupku donošenja odluka, zapravo, žele li građani doista participirati ili, pak, samo imati (normiranu) mogućnost da to čine? ${ }^{23}$

Na potonjem tragu, i kod participacije građana laika u suđenju ističe se da je nejasno koliko su građani laici motivirani za participaciju i koliko je, usto, od njihove participacije moguće imati koristi, s obzirom na to da ne raspolažu stručnim znanjem, u konačnici troše vrijeme i trud, a nije jasno moguće utvrditi prednosti njihova sudjelovanja, posebice stoga što pri dužem razdoblju participacije u suđenju kopni njihova "sposobnost da sagledavaju probleme primarno iz perspektive građana". ${ }^{24}$ Nadalje, pojedini autori ističu opasnost od potpadanja građana laika u suđenju pod utjecaj medija i javnog mnijenja, a jedan od primjera predstavlja tzv. slučaj Nanavati iz 1959. godine u Indiji u kojemu je izrečena oslobađajuća presuda, unatoč mnoštvu dokaza koji su ukazivali na suprotno, što se pripisivalo utjecaju medija na porotnike. ${ }^{25}$ Slično tome, neki autori ukazuju na opasnost od potpadanja građana laika u suđenju pod utjecaj straha, a jedan od najpoznatijih primjera takvog utjecaja predstavlja tzv. slučaj Otegi iz 1997. godine u Španjolskoj. U tom slučaju bila je izrečena oslobađajuća presuda koja je vrlo kritizirana zbog shvaćanja da su porotnici pri odlučivanju bili u strahu od odmazde skupine za koju se smatralo da je optuženik s njome povezan, a sâm slučaj Otegi poslužio je kao poticaj za razmatranje mogućnosti reforme, pa čak i ukidanja porotnog suđenja u Baskiji. ${ }^{26}$ Dakako, mogućnost utjecaja na građane laike u suđenju može potjecati i od cijelog niza drugih razloga, i to ne samo kod porotnih sudova, nego i kod prisjedničkih sudova, kod kojih svi članovi sudskog vijeća ravnopravno mogu odlučiti o pravnim i činjeničnim pitanjima, zbog čega je vrlo

21 Freie, J. F., Participatory democracy, u: D. Levinson; K. Christensen (ur.), Encyclopedia of Community: From the Village to the Virtual World, Volume 1, Sage Publications, Thousand Oaks-London, 2003., str. 162.

22 Ravlić, S., Demokracija u globaliziranom svijetu, u: A. Milardović; N. Jožanc (ur.), Demokracija i postdemokracija, Pan liber, Zagreb, 2013., str. 179.

23 Vidi npr.: Pieterse, J. N., Participatory democratization reconceived, Futures, god. 33, br. 5, 2001., str. 410.

24 Malsch, M., Democracy in the Courts: Lay Participation in European Criminal Justice Systems, Ashgate, Surrey, 2009., str. 25.-26.

25 Potonji utjecaj potvrđen je od strane višeg suda, a zatim i od Vrhovnog suda Indije u predmetu K. N. Nanavati v. State of Maharashtra (AIR 1962 SC 605) te je izrečena osuđujuća presuda (od strane sudaca profesionalaca), a cijeli slučaj poslužio je kao jedan od argumenata za ukidanje porotnog suđenja u Indiji. Vidi pobliže: Badami, N; Chandu, M., Access to Justice in India, u: M. Schmiegelow; H. Schmiegelow (ur.), Institutional Competition between Common Law and Civil Law: Theory and Policy, Springer, Berlin-Heidelberg, 2014., str. 214.-215.; Oshisanya, O., An Almanac of Contemporary and Comparative Judicial Restatements (ACCJR) Supplement II: Public Law, Almanac Foundation, Lagos, 2016., str. 453.; Jaffe, J., After Nanavati The Last Jury Trial in India?, Economic \& Political Weekly, god. 52, br. 32, 2017., str. 18.-20.

Vrhovni sud Baskije ukinuo je oslobađajuću presudu i predmet vratio na ponovno suđenje, što su potvrdili Vrhovni sud Španjolske (STS 364/1998 de 11 de marzo de 1998) i Ustavni sud Španjolske (STC 246/2004 de 20 de diciembre de 2004) te je, naposljetku, izrečena osuđujuća presuda. Vidi pobliže: Jimeno-Bulnes, M.; Hans, V. P., Legal Interpreter for the Jury: The Role of the Clerk of the Court in Spain, Onati Socio-legal Series, god. 6, br. 2, 2016., str. 203; Jimeno-Bulnes, M., A Different Story Line for 12 Angry Men: Verdicts Reached by Majority Rule - The Spanish Perspective, Chicago-Kent Law Review, god. 82, br. 2, 2007., str. 764.; Thaman, S. C., Europe's New Jury Systems: The Cases of Spain and Russia, Law and Contemporary Problems, god. 62, br. 2, 1999. str. 258. 
lako moguće da građani laici preglasaju profesionalne suce, o čemu postoje i primjeri iz prakse hrvatskoga prisjedničkog sudovanja. ${ }^{27}$

S druge strane, postoji shvaćanje o važnosti participacije u postupcima donošenja odluka, i to zbog njezine obrazovne (preko osobnog razvoja građana) i integrativne uloge (preko jačanja osjećaja pripadnosti građana vlastitoj zajednici), kao i zbog njezina doprinosa oživotvorenju dobre vladavine (izradom i primjenom propisa i pravila koja će svakom građaninu biti prihvatljiva), ${ }^{28}$ uz shvaćanje da bi participacija mogla "bitno povećati demokratski legitimitet pravnog sustava". ${ }^{29}$ Tako se ističe da se participacijom "ozakonjuje donošenje odluka" ${ }^{30}$ te da se i sâm građanin, kako navodi Aristotel, "ne određuje (...) točnije ničim drugim nego sudioništvom u sudstvu i vlasti", ${ }^{31}$ a "onaj tko ima moć sudjelovati u savjetodavnoj i sudbenoj vlasti, toga nazivamo građaninom dotične države". ${ }^{32}$

U tom smislu, pojedini autori ističu da participacija građana laika u suđenju ima i važnu ulogu u edukaciji javnosti o pravosudnom sustavu i potrebi njegova poštovanja, čime se, ujedno, utječe na snaženje povjerenja javnosti u taj sustav i daje legitimitet sankcioniranju, ${ }^{33}$ kao i da ima nadzornu ulogu, čime se utječe, inter alia, na suzbijanje korupcije. ${ }^{34}$ Naime, uz načelo javnosti (publiciteta) koje djeluje kao jamac individualnih prava i zbiljnosti otvorenog društva, počivajući na zahtjevu građana za otvorenim i utvrđenim pravnim procedurama za "rješavanje svojih prava i sloboda", ${ }^{35}$ participacija omogućuje određeni stupanj demokratskog nadzora nad državnom vlasti pa bi sve institucije, ili većina njih, trebale omogućiti "barem minimalnu razinu participacije građana”. ${ }^{36}$ Stoga se, kako navodi de Tocqueville, postavljanjem naroda, odnosno jednoga njegova dijela preko instituta porote "na sudačku stolicu (...) upravljanje društvom stvarno stavlja u ruke narodu ili toj klasi”. ${ }^{37}$ Nadalje, pojedini autori naglašavaju da se građani laici u suđenju mogu osloniti na svoje životno iskustvo i poznavanje lokalnih običaja, pomažući tako profesionalnim sucima u kontekstualizaciji i individualizaciji određenog slučaja. Time bi djelovali posve suprotno od, katkad, “šablonskog, krutog i formalističkog rješavanja predmeta, te profesionalne deformacije sudaca"38 čime bi se, ujedno, djelovalo i motivirajuće na suce profesionalce - s obzirom na to da bi se uz građane laike temeljitije morali

27 Vidi pobliže, npr. Urukalo, V., Suci se žale: Porotnici su amateri koji nas mogu preglasati. URL= https://www.slobodnadalmacija.hr/ novosti/hrvatska/clanak/id/311715/suci-se-zale-porotnici-su-amateri-koji-nas-mogu-preglasati. Pristupljeno: 10. ožujka 2019.

Vidi npr.: Pateman, C., Participatory democracy revisited, Perspectives on Politics, god. 10, br. 1, 2012., str. 10.; Michels, op. cit. u bilj. 19.; Struić, G.; Bratić, V., op. cit. u bilj. 1, str. 134.

Malsch, op. cit. u bilj. 24, str. 20.

Radman, Z., Građanstvo i javne politike: Utjecaj različitih modela građanstva na rezultate politike upravljanja prostorom u jadranskim regijama, Politička kultura, Zagreb, 2010., str. 22.

Thaman, S. C., The Nullification of the Russian Jury: Lessons for Jury-Inspired Reform in Eurasia and beyond, Cornell International Law Journal, god. 40, br. 2, 2007., str. 361.

Hans, V. P., Introduction: Lay Participation in Legal Decision Making, Law and Policy, god 25, br. 2, $2003 .$, str. 83. 
pripremiti za suđenje, ali i pažljivije, savjesnije i brižljivije vodili raspravu da bi ih građani laici mogli pratiti - te korigirala "nesavršenost i nepravilnost prava u konkretnim slučajevima". ${ }^{39}$

Iako iz dosad izloženog slijedi da se participaciji građana laika u suđenju pripisuju uloge koje ukazuju na određene prijepore i potencijalne nedostatke, nesporno je i da se participacijom građana laika u suđenju može ostvariti niz njezinih izrazito značajnih uloga koje ne sadrže samo vitalni imperativ suvremene ustavno-demokratske države za demokratizacijom pravosuđa, nego i važnu edukativnu i integrativnu komponentu. Ujedno, u tim njezinim ulogama valjalo bi prepoznati i razloge pro et contra sudjelovanja građana laika u suđenju, kao i ratio njezina uvođenja u pravni poredak pojedine države ili, pak, ukidanja, ali i prijepore koji se s time u vezi uobičajeno susreću.

Imajući u vidu da se uz spomenute uloge participacije građana laika u suđenju često ističe da je riječ "o historijskoj tekovini modernog vremena, koja je još veoma jaka", ${ }^{40} \mathrm{u}$ tolikoj mjeri da se sudjelovanje građana laika u suđenju smatra univerzalnim političkim postulatom, najprije se izlaže način pravnog uređenja kvalifikacija građana laika za njihovu participaciju u porotnom, a zatim i u prisjedničkom suđenju u Hrvatskoj, sve do važećih normativnih rješenja.

\section{POROTNO SUĐENJE U HRVATSKOJ}

Porotni sud, kod kojeg o činjeničnim pitanjima odlučuje porota, a o pravnim sudac, u pravilu se javlja u zemljama angloameričkoga pravnoga kruga, iako ga se može primijetiti i u zemljama europskoga kontinentalnoga pravnog kruga, poput Austrije i Španjolske. Prisjednički sud, kod kojeg i građani laici i suci ravnopravno odlučuju o pravnim i činjeničnim pitanjima, dominantno se javlja u zemljama europskoga kontinentalnoga pravnoga kruga, pa tako i u Hrvatskoj. Međutim, kroz hrvatsku povijest građani laici mogli su participirati i u porotnom suđenju pa bi se ukratko valjalo osvrnuti najprije na razdoblje koje je prethodilo uvođenju prisjedničkog suđenja u hrvatsko zakonodavstvo i pojavu porotnika u Hrvatskoj.

\subsection{POROTNICI U SREDNJEM VIJEKU}

Pojam porotnika može se zamijetiti već u pojedinim srednjovjekovnim statutima hrvatskih gradova. Tako se spominje, primjerice, u Vinodolskom zakonu iz 1288. koji je kao glavno dokazno sredstvo na sudu predviđao svjedoke, a u slučaju da ih nije bilo, optuženom je omogućavao da prisegne na istinitost vlastitih tvrdnji (kod lakših kaznenih djela), odnosno s određenim brojem porotnika (kod težih kaznenih djela), s time da je onaj koji nije uspio naći dovoljan broj porotnika polagao prisegu onoliko puta koliko mu je nedostajalo porotnika (članak 10. i 56. Vinodolskog zakona). ${ }^{41}$ Smatra se da je optuženi mogao birati porotnike između članova

\footnotetext{
39 Ibid.

40 Bayer, V., Suci porotnici, Zbornik Pravnog fakulteta u Zagrebu, god. 5, br. 3-4, 1955., str. 144.

41 Margetić, L., Vinodolski zakon, Adamić-Nakladni zavod Globus, Rijeka-Zagreb, 2008., str. 69.
} 
svoje obitelji, a tek ako ih nije uspio naći (u dovoljnom broju), imao je pravo položiti prisege koje su nedostajale, što je vrlo slično rješenju sadržanom u Krčkom statutu (Statuta Vegliae) na latinskom iz 16. stoljeća koji je omogućavao strankama da biraju porotnike među svojim rođacima, a tek ako nisu imali rođaka, za porotnike su mogli birati ostale mještane. ${ }^{42}$

Iako postoje i raniji primjeri sličnih rješenja, poput splitske isprave iz 1174. kojom se uređivalo svjedočenje žena pred sudom ${ }^{43}$ - koje su, u slučaju da nisu imale rođaka, mogle birati polovicu porotnika među mještanima (premda nije jasno tko je imao pravo birati drugu polovicu porotnika i između koga) ${ }^{44}$ - značenje porote i porotnika u tim srednjovjekovnim dokumentima nije identično njihovu suvremenom značenju. Naime, iz tih dokumenata proizlazi da porotnici ipak nisu bili članovi suda, nego su samo polagali prisegu, tzv. rotu, što je staroslavenska riječ na koju upućuje i etimologija riječi porotnik, i to upravo u značenju prisege, zakletve. ${ }^{45}$ Njome su imali priliku pomoći optuženiku zaklinjući se u njegovu vjerodostojnost, zalažući tako "dušu svoju za dušu povodca, jer se kunu: da mu je prisega čista i prava" 46 pa se može zaključiti da su porotnici iz srednjovjekovnih hrvatskih dokumenata predstavljali dokazno sredstvo, a njihove povijesne uzore moguće je naći u institutu prisežnih pomoćnika u starogermanskom pravu (Eideshelfer). ${ }^{47}$

Do pojave porotnika u njihovu suvremenu značenju na području današnje Hrvatske došlo je polovicom devetnaestog stoljeća na valu širenja zahtjeva za uvođenje porotnog suđenja diljem tadašnje Europe počevši od njihova uzora u francuskom pravu i širenja tih zahtjeva, inter alia, u Austriju preko koje je došlo do uvođenja porotnog suđenja i na hrvatskom području.

\subsection{POROTNO SUĐENJE OD 1848. DO 1929.}

U liberalnim programskim dokumentima devetnaestog stoljeća i vrlo snažnom nastojanju za objektivnim suđenjem, kao jednim od važnih, nosećih stupova u ostvarivanju zaštite individualnih sloboda i prava od utjecaja države, mogao se uočiti zahtjev za uvođenjem porotnog suđenja, često vezivan uz zahtjev za uvođenjem slobode tiska. ${ }^{48} \mathrm{~S}$ obzirom na dalekosežnost utjecaja tiska i slaba jamstva neovisnosti sudaca u to vrijeme, smatralo se važnim osigurati porotno suđenje upravo za tiskovne delikte, koji su redovito imali "političko obilježje". ${ }^{49}$

42 Ibid., str. 114.

43 Smičiklas, T., Codex diplomaticus regni Croatiae, Dalmatiae et Slavoniae. Volumen II. Diplomata saeculi XII. Continens - Diplomatički zbornik Kraljevine Hrvatske, Dalmacije i Slavonije. Svezak 2. Listine XII. vijeka (1101-1200), Tisak dioničke tiskare, Zagreb, 1904., str. 138.-139.

Mažuranić, V., Prinosi za hrvatski pravno-povjestni rječnik. Svezak I., Knjižarnica Jugoslavenske akademije (dioničke tiskare) (Gjuro Trpinac), Zagreb, 1908., str. 1022. Zagreb, 2004., str. 237. 
Do uvođenja porotnog suđenja u kontinentalnoj Europi, po uzoru na englesku porotu, ${ }^{50}$ najprije je došlo u Francuskoj u kojoj je Dekretom od 16. do 29. rujna 1791. o sigurnosnoj policiji, kaznenom pravosuđu i uvođenju porotnika ${ }^{51} \mathrm{u}$ članku II. (pod glavom XI.) bilo određeno da za porotnika može biti izabran samo onaj građanin koji ispunjava uvjete za elektora (électeur), osim policijskih službenika, sudaca, javnih tužitelja i drugih čija se dužnost smatrala nespojivom s porotničkom dužnošću. Pritom, Ustavom od 3. rujna $1791 .^{52}$ bilo je propisano da za elektore (koji su birali zastupnike i druge dužnosnike) mogu biti izabrani samo aktivni građani (citoyens actifs) koji su udovoljavali brojnim uvjetima iz članka II. (pod glavom III., poglavljem I., odjeljkom II.) Ustava iz 1791. Njime je određeno da aktivnim građaninom može postati francuski državljanin s navršenih 25 godina i prebivalištem u određenom gradu ili kantonu tijekom određenog razdoblja, uz potvrdu da je platio izravan porez u vrijednosti trodnevnog rada i uz obvezu da je položio građansku prisegu, kao i da je, uza sve to, upisan u zapisnik Nacionalne garde u mjestu njegova prebivališta te da nema status plaćene posluge. Budući da je uvjetima za elektora (i porotnika), udovoljavao vrlo mali broj francuskih građana, po reformi 1853. i 1872. ti uvjeti su ublaženi pa je porotničku dužnost mogao obnašati svaki francuski državljanin s navršenih 30 (ali ne stariji od 70) godina koji je znao čitati i pisati francuski te imao politička i građanska prava, osim ako je od porotničke dužnosti bio isključen zbog moralnih (npr. osuđenici), imovinskih (npr. dužnici) i razloga nespojivosti dužnosti. ${ }^{53}$ Po uzoru na Francusku, porotno suđenje uvedeno je i u Belgiji 1830., u Portugalu 1852., u Italiji 1865., u Rumunjskoj 1886., u Španjolskoj 1888., u Mađarskoj 1897., ${ }^{54}$ ali i u Austriji koju posebno valja izdvojiti u kontekstu utjecaja na hrvatska područja.

Austrija je kazneno suđenje uz sudjelovanje porote prvi put propisala tzv. Pillersdorfovim ustavom od 25. travnja 1848. u § 29., dok je uređivanje njezina uvođenja prepušteno posebnom zakonu. ${ }^{55} \mathrm{Na}$ toj podlozi, do njezina uvođenja u austrijski pravni sustav, a time i u Dalmaciju, i u Istru koje su pripadale austrijskom pravnom području, došlo je na temelju Provizorne naredbe o postupku u tiskovnim predmetima od 18. svibnja 1848. u čijem je $\S 2$. propisana nadležnost porote za odlučivanje o krivnji ili nedužnosti, a za porotničku dužnost zahtijevalo se da je riječ o muškom austrijskom državljaninu s navršene 24 godine, samostalnom, sa svim građanskim pravima is prebivalištem u mjestu (ili neposrednoj okolici) tiskovnog suda, uz izuzetak svećenika i činovnika (zbog nespojivosti dužnosti), sukladno $§ 46 .{ }^{56}$ Nakon što je Ožujskim ustavom od 4. ožujka 1849. predviđen institut porote za političke i tiskovne prijestupe i teže zločine prema $\S 103$., ubrzo su carskim patentima izdana dva propisa: Zakon protiv zlouporabe tiska od 13. ožujka 1849. i Propis o postupku u predmetima tiskovnih prijestupa

50 Ibid. Više o razvoju engleske porote vidi, npr., u: Masschaele, J., Jury, state, and society in medieval England, Palgrave Macmillan, New York, 2008.

51 Décret concernat la police de sûreté, la justice criminelle et l'établissement des jurés. Carette, A. A., Lois annotées ou Lois, décrets, ordonnances, avis du conseil d'état, Pouleur, Paris, 1843., str. 155.-162.

52 Assemblée Nationale, La Constitution française, Présentée au Roi par l' Assemblée Nationale, le 3 septembre 1791, Imprimerie de Prudhomme, Paris, 1791.

53 Baldwin, S. E., French Jury System, Michigan Law Review, god. 2, br. 7, 1904., str. 598.

54 Bayer, op. cit. u bilj. 16, str. 33.; Forsyth, op. cit. u bilj. 12, str. 312.

55 Pastović, D., Sloboda tiska i porotna sudbenost u Istri 1848./1849., Zbornik Pravnog fakulteta Sveučilišta u Rijeci, god. 36, br. 2, 2015., str. 726.-727. 
od 14. ožujka 1849., dok je Provizorni propis o sastavljanju porotničkih imenika za tiskovne sudove uslijedio 11. rujna $1849.5^{57}$

Upravo pod utjecajem austrijskih tiskovnih zakona od 13. i 14. ožujka 1849. i odredbi o poroti, na području Hrvatske i Slavonije najprije je bilo uvedeno porotno suđenje za tiskovne delikte Privrĕmenim zakonom o štampi od 9. svibnja 1849. godine. ${ }^{58}$ Iako njime nisu predviđeni uvjeti za porotničku dužnost, bilježi se shvaćanje o potrebi da u njoj "sjede pošteni, sposobni i nepristrani ljudi, proti kojim ne zna ništa prigovoriti ni tužitelj ni tuženi" ${ }^{59}$ da bi mogao "slobodni građanin slobodnom građaninu suditi" ${ }^{60}$ Istovremeno, Provizorni propis o sastavljanju porotničkih imenika za tiskovne sudove od 11. rujna 1849. predviđao je da porotničku dužnost može obnašati muškarac s navršenih 30 godina koji znade čitati i pisati te je nastanjen barem godinu dana u dotičnoj općini i plaća od 5 do 10 forinti godišnjeg poreza (ovisno o veličini mjesta, s više ili manje od 10.000 stanovnika) ili, alternativno, po osobnim karakteristikama raspolaže aktivnim izbornim pravom u dotičnoj općini u sastavu austrijskih krunovina (§ 2.), izuzevši: dušobrižnike, pučke učitelje, službenike i aktivne vojne osobe (§3.), štićenike, rasipnike, osobe s duševnim ili tjelesnim manama, poput gluhih, slijepih, nijemih ili slaboumnih (§ 4.), okrivljene za zločin ili težak prijestup političke naravi motiviran koristoljubljem ili vrijeđanjem javnog ćudoređa, kao i osuđene na zatvorsku kaznu od barem šest mjeseci i one čija je imovina pod stečajem (§5.), dok su pravo otklanjanja porotničke službe imali stariji od 65 godina te oni koji su u svojstvu glavnog ili zamjenskog porotnika u jednom zasjedanju već ispunili porotničku dužnost (§ 6.). ${ }^{61}$ Ipak, prvi i zadnji postupak pred porotnim sudom koji je vođen na temelju Privrĕmenog zakona o štampi od 9. svibnja 1849. godine održan je 6. veljače 1850., kada je jedan član porote u znak protesta zbog tog Zakona koji je donesen na temelju izvanrednih saborskih ovlasti napustio suđenje, a nedugo zatim Bachovim apsolutizmom ukinuto je suđenje uz sudjelovanje porote - kako u Hrvatskoj i Slavoniji, tako i u Dalmaciji i Istri koje su pripadale austrijskom pravnom području. ${ }^{62}$

Porotno suđenje ponovno je uvedeno u hrvatsko pravosuđe Zakonom od 17. svibnja 1875. o kaznenom postupku u poslovih tiskovnih za kraljevine Hrvatsku i Slavoniju ${ }^{63}$ (§ 14.-64), dok su uvjeti za tu dužnost utvrđeni Zakonom od 17. svibnja 1875. o propisu, kako se imadu

57 Ibid., str. 736.-741.

58 Čepulo, op. cit. u bilj. 15, str. 928.-930. Potrebno je spomenuti da je potreba za prevođenjem austrijskih tiskovnih zakona od 13. i 14. ožujka 1849. na jezike austrijskih pokrajina usporila njihovu bržu objavu pa je do njihove objave, primjerice, za Gornju Austriju i Dalmaciju došlo 30. ožujka 1849., a za Austrijsko primorje koje je uključivalo Istru tek 31. svibnja 1849. Pastović, op. cit. u bilj. 55, str. 748.

Šulek, B., Izabrani članci, Jugoslavenska akademija znanosti i umjetnosti, Zagreb, 1952., str. 136. Riječ je o članku istog autora koji je pod naslovom Porota objavljen 1850. godine u časopisu Slavenski jug, br. 20, 21, 22.

6o Ibid., str. 138.

61 Pastović, op. cit. u bilj. 55, str. 745.-746.

62 Bayer, op. cit. u bilj. 40, str. 148.; Čepulo, op. cit. u bilj. 15, str. 930.

63 Sbornik zakona i naredabah valjanih za kraljevinu Hrvatsku i Slavoniju. Godina 1875. (Komad I.-XXXIX. Br. 1.-88.), Brzotiskom tiskare "Narodnih Novinah", Zagreb, 1876., str. 373.-390. Iako su i sâmi saborski zastupnici bili neskloni širenju nadležnosti porotnih sudova izvan tiskovnih delikata, stoga što bi laički element teško bilo nadzirati, neovisno o cenzusu koji je smjerao isključenju donjih slojeva stanovništva od uključivanja u porotno suđenje, otpor širenju nadležnosti zacijelo bi se mogao pripisati pritisku Budimpešte "koja nikako nije željela slobodniji politički život u autonomnom dijelu svoje države, čiju je autonomiju ionako tolerirala nevoljko i iz nužde” (Čepulo, op. cit. u bilj. 15, str. 953). 
sastavljati porotnički imenici za sudove tiskovne u kraljevini Hrvatskoj i Slavoniji. ${ }^{64}$ Potonji Zakon - koji je izrađen po uzoru na austrijski Zakon od 23. Svibnja 1873, o tom, kako se sastavljaju imenici porotnikah ${ }^{65}$ - vrlo je detaljno predvidio kvalifikacije za porotnika, kao i skupine osoba koje nisu mogle obnašati porotničku dužnost. Porotnik je mogao biti samo muškarac, državljanin s navršenih 30 (ali ne više od 60) godina, koji je znao čitati, pisati i najmanje je godinu dana prebivao u određenoj općini te plaćao izravan porez od minimalno 20 forinti na godinu. Alternativno, umjesto imovinskog cenzusa, bio je potreban intelektualni cenzus: uz navršene 24 godine, zahtijevala se i titula doktora znanosti ili, pak, završeno tehničko više učilište s dobrim uspjehom ili članstvo u Jugoslavenskoj akademiji znanosti i umjetnosti ili zvanje odvjetnika, kraljevskog bilježnika ili profesora (§ 2.). S druge strane, Zakon je zbog nespojivosti dužnosti iz porotničke službe isključio svećenike, učitelje pučkih škola, suce, državne službenike (osim profesora), vojnike, namještenike pošta, željeznica, brzojava i parobrodarstva (§ 3.), dok su nesposobnima za porotničku službu proglašeni svi koji tu službu nisu mogli obnašati zbog tjelesnih ili psihičkih poremećaja ili su djelomice lišeni građanskih prava (poput rasipnika i onih nad čijom je imovinom otvoren stečajni postupak), kao i oni koji su osuđeni u kaznenom postupku ili su pod istragom, optužbom ili u kazni te oni koji po zakonu nisu imali pravo biti birani u zastupstvo općine (§ 4.). Naposljetku, izrijekom je bilo propisano i da porotničku službu nisu morali prihvatiti zastupnici obaju sabora tijekom njihova zasjedanja, dvorski službenici, javni učitelji, liječnici, vidari i ljekarnici koji su bili proglašeni prijeko potrebnima za njihovu službu ili dotičnu općinu za sljedeću godinu, ali i oni koji su već udovoljili porotničkoj dužnosti za idućih dvanaest mjeseci (§ 5.).

Istovremeno, u Dalmaciji i Istri, kao dijelovima austrijskoga pravnog područja, na snazi je bio Kazneni postupnik ${ }^{66}$ - koji je počivao na usavršenim postulatima koje je sadržavao francuski Code d'Instruction Criminelle od $1808 .{ }^{67}$ - i Zakon od 23. Svibnja 1873, kojim se uvodi postupnik kazneni, ${ }^{68}$ kojim je porotno suđenje bilo uvedeno za sva teža kaznena djela, a ne samo za tiskovne delikte kao u Hrvatskoj i Slavoniji. ${ }^{69}$ Pored toga, na snazi je bio i ranije spomenuti Zakon od 23. Svibnja 1873, o tom, kako se sastavljaju imenici porotnikah, prema kojemu je izrađen Zakon od 17. svibnja 1875. o propisu, kako se imadu sastavljati porotnički imenici za sudove tiskovne u kraljevini Hrvatskoj i Slavoniji koji predstavlja njegovu vjernu "kopiju". ${ }^{70} \mathrm{U}$ Međimurju, kao dijelu ugarskoga pravnog područja, porotno suđenje najprije je bilo uvedeno za tiskovne delikte 1867., a zatim je 1896.-1897. bilo prošireno na sva teža kaznena djela, i to na temelju Zakonskog članka XXXIII. od 1896., Zakonskog članka XXXIII. od 1897. i Zakonskog članka XXXIV. od $1897 .{ }^{71}$ Budući da su se spomenuti zakonski članci u bitnom podudarali

64 Sbornik zakona i naredabah valjanih za kraljevinu Hrvatsku i Slavoniju. Godina 1875. (Komad I.-XXXIX. Br. 1.-88.), Brzotiskom tiskare “Narodnih Novinah”, Zagreb, 1876., str. 368.-372.

65 Dèržavo-zakonski list za kraljevine i zemlje, zastupane u vieću cesarevinskom. Godina 1873., Iz c. kr. dèržavne i dvorske štamparije, Beč, 1873., str. 503.-508.

66 Dèržavo-zakonski list za kraljevine i zemlje, zastupane u vieću cesarevinskom. Godina 1873., Iz c. kr. dèržavne i dvorske štamparije, Beč, 1873., str. 400.-498.

67 Vidi pobliže: Bayer, op. cit. u bilj. 16, str. 40.

68 Dèržavo-zakonski list za kraljevine i zemlje, zastupane u vieću cesarevinskom. Godina 1873., Iz c. kr. dèržavne i dvorske štamparije, Beč, 1873., str. 397.-399.

69 Bayer, op. cit. u bilj. 40, str. 149.

70 Bayer, op. cit. u bilj. 16, str. 48. 
s austrijskim modelom porotnog sustava, ${ }^{72}$ može se općenito zaključiti da su se na području današnje Hrvatske u bitnosti poklapale kvalifikacije za porotnika, kao i razlozi zbog kojih pojedine osobe nisu mogle obnašati porotničku dužnost. S izuzetkom Privrĕmenog zakona o štampi od 9. svibnja 1849. godine koji nije sadržavao odredbe o kvalifikacijama za porotničku dužnost, ni razloge nemogućnosti obnašanja porotničke dužnosti, kasniji propisi detaljno su ih uređivali po uzoru na austrijska pravna rješenja te materije, a ona su se u nemalom dijelu poklapala s francuskim pravnim rješenjima iz 19. stoljeća u pogledu kvalifikacija koje se tiču minimalne dobi, državljanstva, poznavanja čitanja i pisanja te isključenja zbog postojanja moralnih i imovinskih razloga te razloga nespojivosti dužnosti. Takvim pristupom značajno je ograničen broj onih koji tim uvjetima mogu udovoljiti, što je istovremeno rezultiralo razmjerno malom mogućnošću ostvarivanja participacije i značajnih uloga koje joj se pripisuju.

Stupanjem na snagu Ustava Kraljevine Srba, Hrvata i Slovenaca od 28. lipnja $1921 .{ }^{73}$ kojim je bilo određeno da redovni sudovi sude "sve krivice štampom učinjene" (članak 13. stavak 3.), a potom i Zakonika o sudskom krivičnom postupku za Kraljevinu Srba, Hrvata i Slovenaca od 16. veljače 1929., ${ }^{74}$ kao i Zakona o uređenju redovnih sudova za Kraljevinu Srba, Hrvata i Slovenaca od 18. siječnja $1929 .{ }^{75}$ - koji nisu predviđali porotne sudove - sustav porotnog suđenja na području današnje Hrvatske je napušten, a suđenje je stavljeno u isključivu nadležnost sudaca profesionalaca, što je, uz određene iznimke, ${ }^{76}$ potrajalo sve do uvođenja prisjedničkog suđenja u hrvatsko zakonodavstvo.

\section{PRISJEDNIČKO SUĐENJE U HRVATSKOJ}

Pri uvodnom osvrtu na prisjedničko suđenje u Hrvatskoj najprije bi valjalo spomenuti da je korijene sudova sa stalnim i povremenim sucima koji mogu ravnopravno odlučiti i o pravnim, i o činjeničnim pitanjima moguće naći u srednjovjekovnom njemačkom pravu te da su polovicom 19. stoljeća primarno zbog nacionalnih razloga dobili prednost pred porotom za koju se isticalo da je "engleskog porijekla i prema tome strana čisto njemačkom pravnom razvoju". ${ }^{77}$ Smatrajući da se takvim sudovima nastavlja stara njemačka tradicija tzv. skabinskih sudova (Schöffengericht), kod kojih su građani laici mogli odlučivati o pravnim i činjeničnim pitanjima, te sudove najprije su uveli Hanover (1850.), Württemberg i Saska (1869.), nakon čega je došlo

72 Bayer, op. cit. u bilj. 16, str. 50.

73 Službene novine Kraljevine Srba, Hrvata i Slovenaca od 28. lipnja 1921., broj 142A.

Službene novine Kraljevine Srba, Hrvata i Slovenaca od 23. veljače 1929., broj 45-XX.

Službene novine Kraljevine Srba, Hrvata i Slovenaca od 25. siječnja 1929., broj 20-X.

Građani laici ostali su participirati u suđenju, i to kao tzv. počasni suci u trgovačkim sporovima, prema Uredbi o počasnim sudijama (Službene novine Kraljevine Jugoslavije od 3. kolovoza 1933., broj 174-XLIX), a pored svoje specifične struke i znanja (trgovine, brodarstva ili rudarstva) morali su ispunjavati i niz propisanih uvjeta, posebice da su državljani Kraljevine Jugoslavije, imaju 30 godina, da su "svojevlasni”, da stanuju u blizini dotičnog suda ili u njegovoj blizini, ali i da nisu pod stečajem ili osuđeni za neko kazneno djelo "s kojim je vezan gubitak časnih prava ili javne službe", odnosno da se ne nalaze pod istragom zbog takvih djela, kao i da sa sucima dotičnog suda ne stoje ni u kakvom odnosu iz § 16. Zakona o sudijama redovnih sudova (članak 6.). 
do njihova uvođenja i u Srbiji (1871.), Bosni i Hercegovini (1891.), Rusiji (1917.), Italiji (1931.) i Austriji (1934.). ${ }^{78}$

Posebno je zanimljivo da su u drugoj polovici 19. stoljeća građani laici kao tzv. prisežnici sudjelovali u suđenju i na području kraljevine Hrvatske i Slavonije, i to u prekršajnim postupcima u okviru kotarskih sudova, u čijem su se sastavu nalazili jedan stalni sudac i dvojica prisežnika. Prisežnička služba tako je bila uvedena kao svojevrsni "supstitut porotnog suđenja"79 na temelju § 393. Zakona od 17. svibnja 1875. o kaznenom postupku. ${ }^{80}$ Njime je služba sudskog prisežnika proglašena počasnom te ju je mogao obnašati svaki pripadnik kraljevine Hrvatske i Slavonije s navršenih 30 godina, koji je bio samostalan, imao sva građanska prava i bio "pismen i neporočan, uredovnomu jeziku vješt” (§ 394.). Izuzetak su činili svećenici, pučki učitelji, članovi aktivne vojske i činovnici "od sudbene i političke uprave", a nisu je morali prihvatiti osobe zdravstvene i uredničke struke, ako bi "služba patila odsutnošću njihovom" (§ 395.). Ipak, uz shvaćanje da su se prisjednici u praksi pokazali nesvrhovitim, ${ }^{81}$ Zakonom od 6. srpnja 1888. kojim se preinačuju i nadopunjuju neke ustanove zakona od 17. svibnja 1875. o kaznenom postupku (sbornik zakonah i naredabah br. 30, god. 1875) ${ }^{82}$ dolazi do ispuštanja prisjednika iz dotadašnjih zakonskih odredbi (članak IV.).

Nastojanja za participacijom građana laika u suđenju u Hrvatskoj moguće je pratiti i u vrijeme Drugoga svjetskog rata. Iz tog vremena valja izdvojiti Okružnicu Nacionalnog Komiteta Oslobođenja Jugoslavije od svibnja 1944., kojom je bila istaknuta preporuka da članove sudskog vijeća uz stalne suce čine i povremeni suci, te članak 7. Uputstva Zemaljskoga antifašističkog vijeća narodnog oslobođenja Hrvatske od studenoga 1944. o preuređenju sudova, kojim je određeno da se, uz predsjednika suda i njegova zamjenika, sudovi sastoje od povremenih sudaca (prisjednika) čija je dužnost bila počasna, a mogao ju je obnašati svaki "punoljetni i neporočni građanin ili građanka" ${ }^{83}$ Do uvođenja prisjedničkog suđenja u hrvatsko zakonodavstvo dolazi 1945., a nakon toga može se pratiti nekoliko razdoblja koja su bila obilježena donošenjem četiriju ustava, jednog ustavnog zakona, ali i nekoliko ključnih zakona koji su na toj podlozi doneseni, regulirajući ovu materiju: od 1945. do 1954., od 1954. do 1963., od 1963. do 1974., od 1974. do 1990. i od 1990. do danas. ${ }^{84}$

78 Vidi npr.: Dubber, M.; Pihlajamäki, H., Lay participation in modern law: a comparative historical analysis, Comparative Legal History, god. 3, br. 2, 2015., str. 227.; Bayer, op. cit. u bilj. 16, str. 52.; Bayer, op. cit. u bilj. 40, str. 148.-149.

79 Čepulo, D., Izgradnja modernog hrvatskog sudstva 1848-1918., Zbornik Pravnog fakulteta u Zagrebu, god. 56, br. 2-3, 2006., str. 368.

80 Sbornik zakonah i naredabah valjanih za kraljevinu Hrvatsku i Slavoniju. Godina 1875. (Komad I.-XXXIX. Br. 1.-88.), Brzotiskom tiskare "Narodnih Novinah", Zagreb, 1876., str. 235.-353.

81 Čepulo, op. cit. u bilj. 79.

82 Sbornik zakonah i naredabah valjanih za kraljevinu Hrvatsku i Slavoniju. Godina 1888. (Komad I.--XVIII. Br. 1.-79.), Tiskarski zavod “Narodnih Novinah”, Zagreb, 1888., str. 305.-331.

83 Čulinović, F., Porota u Jugoslaviji, Zbornik Pravnog fakulteta u Zagrebu, god. 4, br. 1-2, 1954., str. 49.-50.

84 Za razliku od dosadašnjih istraživanja prisjedničkog suđenja, koja su uglavnom različito pristupala određivanju promatranog razdoblja (npr. Kamhi, S.; Čalija. B., Sistem porote u našoj zemlji i problemi vezani za učešće građana u vršenju pravosuđa, Svjetlost, Sarajevo, 1974. ili Ljubanović, op. cit. u bilj. 38), u ovom radu ono se razmatra kroz ukupno pet razdoblja, od 1945. do danas: prvo, kako bi se obuhvatila cjelokupna povijest prisjedničkog suđenja od njezina uvođenja u hrvatsko zakonodavstvo do današnjih dana; drugo, kako bi se svako od tih razdoblja moglo kontekstualizirati, napose s obzirom na to da su ona obilježena donošenjem četiriju ustava, jednog ustavnog zakona, ali i nekoliko ključnih zakona za temu ovog rada koji su na toj ustavnoj podlozi doneseni; treće, iz razloga preglednosti i nastojanja za usustavljivanjem ove materije. Pritom, za razliku od pojedinih autora koji posebno ističu razdoblje od 1941. do 1945. (vidi npr.: Jovanović, M., Porota u pravosuđu Jugoslavije, Savremena administracija, Beograd, 1958.), u ovom radu ono se izostavlja iz posebnog prikaza, s obzirom na to da tada nije ni moglo biti riječi o participaciji građana 


\subsection{RAZDOBLJE OD 1945. DO 1954.}

Po završetku Drugoga svjetskog rata participacija građana laika u suđenju propisana je Zakonom o uređenju narodnih sudova ${ }^{85}$ kojim je bilo određeno da prvostupanjski sudovi u pravilu sude u vijećima u kojima uz suca sudjeluju i dva prisuditelja (članak 13. stavak 1.), koji su imali ista prava kao i sudac (članak 14. stavak 2.). Pod pojmom prisuditelja - koji bi valjalo povezati s pojmom narodnih zasjedatelja iz članka 103. Ustava Saveza Sovjetskih Socijalističkih Republika iz 1936., ${ }^{86}$ kao građana laika koji su sudjelovali u suđenju - zakonodavac je odredio one osobe koje se povremeno pozivaju na sud radi obnašanja sudačke dužnosti (članak 14. stavak 1.). Za prisuditelja je mogao biti izabran građanin s biračkim pravom (članak 16. stavak 2.), a sve prisuditelje, od kotarskih sudova do saveznoga Vrhovnog suda, birala su odgovarajuća narodna predstavnička tijela (članak 17. stavak 1.). Budući da su prema članku 3. Zakona o biračkim spiskovima ${ }^{87}$ biračko pravo imali muški i ženski državljani Jugoslavije s navršenih 18 godina, ali i svi vojnici Jugoslavenske vojske i svi bivši borci NOB-a i partizanskih odreda Jugoslavije bez obzira na njihove godine, proizlazi da su bila potrebna samo dva uvjeta za izbor prisuditelja: prvi, jugoslavensko državljanstvo i, drugi, minimalna dob od navršenih 18, odnosno, uz određene pretpostavke, i manje od 18 godina.

Nakon što je Ustavom Federativne Narodne Republike Jugoslavije ${ }^{88}$ iz 1946. propisano da se vijeća kotarskog i okružnog suda kod suđenja u prvom stupnju sastoje od "sudaca i sudaca-porotnika” koji su u suđenju ravnopravni ${ }^{89}$ (članak 119. stavak 2.), novi pojam "sudaca-porotnika" - kojim se nastojalo u bitnosti eliminirati "ono sekundarno pa i inferiorno u funkciji što je sadržavao i 'prisjednik' i 'prisuditelj”"90 iz ranijih dokumenata - preuzeo je i Zakon o potvrdi i izmjenama i dopunama Zakona o uređenju narodnih sudova od 26. kolovoza 1945. ${ }^{91}$ Naime, potonji zakon najprije je odredio da su suci one osobe koje obnašaju sudačku dužnost kao jedinu službu i jedino zanimanje, a suci porotnici osobe koje se, zadržavajući svoje zanimanje, povremeno pozivaju u sud radi obnašanja sudačke dužnosti (članak 16. stavak 2.). Za suca porotnika, ali i suca, mogao je biti izabran svaki građanin kojemu nije bilo oduzeto bilo

laika u suđenju u današnjem, općeprihvaćenom značenju, tj. da "pored stalnih sudaca koji sudačku funkciju vrše kao zanimanje, u suđenju sudjeluju i povremeni, neprofesionalni suci uzeti iz naroda” (Ljubanović, op. cit. u bilj. 38, str. 21.).

85 Službeni list Demokratske Federativne Jugoslavije, broj 67/1945. Prema tom Zakonu, pravosuđe su vršili kotarski i okružni sudovi te Vrhovni sud Vojvodine, vrhovni sudovi pojedinih federalnih jedinica i Vrhovni sud Demokratske Federativne Jugoslavije, a posebnim zakonom mogli su biti osnovani i posebni sudovi (članak 1. stavci 1. i 2.).

86 Конституция Союза Советских Социалистических Республик, URL=http://constitution.garant.ru/history/ussr-rsfsr/1936/. Pristupljeno: 10. ožujka 2019. Odredbu o sudjelovanju zasjedatelja u suđenju sadržavao je i članak 108. Ustava Ruske Sovjetske Federativne Socijalističke Republike (Конституция Российской Советской Федеративной Социалистической Республики) іz 1937. URL=http://constitution.garant.ru/history/ussr-rsfsr/1937/. Pristupljeno: 10. ožujka 2019.

87 Službeni list Demokratske Federativne Jugoslavije, broj 59/1945.

88 Službeni list Federativne Narodne Republike Jugoslavije, broj 10/1946. Prema tom Ustavu pravosudna tijela bila su: Vrhovni sud Federativne Narodne Republike Jugoslavije, vrhovni sudovi republika i autonomnih pokrajina, okružni i kotarski sudovi (članak 115.), dok su ustrojstvo i nadležnost vojnih sudova određeni saveznim zakonom, a zakonom su se mogli osnivati posebni sudovi za određene vrste sporova.

89 U Ustavu Narodne Republike Hrvatske (Narodne novine, broj 7/1947) identična je odredba o sucima porotnicima (članak 111 stavak 2.) kao i u Ustavu iz 1946., a pod pravosudnim tijelima navedeni su Vrhovni sud, okružni i kotarski sudovi, s time da su se zakonom mogli osnivati posebni sudovi za određene vrste sporova (članak 107.).

90 Jovanović, op. cit. u bilj. 84, str. 60. 
koje političko ili građansko pravo (članak 20. stavak 1.), iz čega slijedi da ni suci nisu morali biti diplomirani pravnici, s obzirom na to da za njihov izbor nije bio naveden uvjet završenoga pravnog fakulteta. ${ }^{92}$ Usto, pri izboru sudaca i sudaca porotnika moralo se uzeti u obzir da dotična osoba može izvršavati zadaće sudova u vršenju pravosuđa (članak 20. stavak 2.), iako iz te odredbe nije posve jasno kako se to, i prema kojim kriterijima utvrđivalo. Nadalje, kod suđenja maloljetnicima, prema Zakonu o krivičnom postupku ${ }^{93}$ sudac porotnik morao je imati i iskustvo u odgoju djece (članak 314.), ali nije pobliže određeno razdoblje tog iskustva, ni ostali detalji vezani uz utvrđivanje te kvalifikacije. Na temelju Ustava iz 1946., suce i suce porotnike okružnog suda u okrugu ili gradu birao je narodni odbor okruga ili grada, a suce i suce porotnike kotarskog suda birao je narodni odbor kotara ili grada (članak 121. stavci 3. i 4.). ${ }^{94}$

Iako je i Zakonom o uređenju i nadležnosti vojnih sudova u Jugoslavenskoj armiji ${ }^{95}$ bilo određeno sudjelovanje laika, i to propisivanjem da u suđenju pred vojnim sudovima uz vojne suce sudjeluju prisuditelji (i njihovi zamjenici), valjalo bi spomenuti da su vojni prisuditelji (i njihovi zamjenici) birani iz određenog kruga osoba koje je kvalificirao njihov čin, odnosno status. Tako ih je predsjedništvo narodnoga predstavničkog tijela dotične federalne jedinice biralo isključivo iz redova generala, admirala, oficira, podoficira i boraca (članak 24. stavak 3.). Već sljedeće godine donesen je Zakon o potvrdi i izmjenama i dopunama Zakona o uređenju i nadležnosti vojnih sudova u Jugoslavenskoj armiji od 24. kolovoza $1945 .{ }^{96}$ kojim se odstupilo od ustavnog izričaja i korištenja pojma suca porotnika te od pojma prisuditelja koji je korišten u prethodnom zakonu (iz 1945.). Naime, zakonom iz 1946. propisano je da u okviru vojnih sudova sude predsjednik suda (ili njegov zamjenik) i dvojica "sudaca" (članak 24. stavak 1.) koji se biraju iz redova oficira, ali i drugih redova vojske i struka, s time da svoju sudačku dužnost obnašaju uz redovnu dužnost u vojsci (članak 23. stavak 3.). Za razliku od dotadašnjeg rješenja, suce vojnih sudova (dakle, suce porotnike) birao je "vrhovni komandant Jugoslavenske armije" (članak 26. stavak 1.). Takvu sličnu odredbu sadržavao je i Zakon o vojnim sudovima ${ }^{97}$ iz 1947., no ipak s tom razlikom što je njime prihvaćen ustavni pojam "sudaca-porotnika" koji su birani iz redova oficira i podoficira, pri čemu su sudačku dužnost morali obnašati uz svoju redovnu dužnost (članak 13. stavak 3.), a birao ih je "Vrhovni komandant oružanih snaga" na prijedlog ministra narodne obrane (članak 14. stavak 2.). Također, valjalo bi istaknuti da je pojam sudaca porotnika korišten i u Zakonu o uređenju i postupku sudova socijalnog osiguranja ${ }^{98}$ kojim je određeno da će ih predsjednik suda socijalnog osiguranja odabrati među sucima porotnicima okružnog suda prema utvrđenom redoslijedu i da, po mogućnosti, trebaju biti “iz redova osiguranika" (članak 2. stavak 6.).

Takav pristup obrazlagao se shvaćanjem da bi se zahtjevom za pravnom strukom moralo ponovno vratiti u službu stare suce "sa svima ožiljcima starog režima na sebi” (Jovanović, op. cit. u bilj. 84, str. 55.). Ipak, zahtjev za pravnom strukom profesionalnih sudaca postavljen je novim zakonom iz 1954. Službeni list Federativne Narodne Republike Jugoslavije, broj 97/1948.

U skladu s time, Ustavom Narodne Republike Hrvatske iz 1947. određeno je da predsjednika, suce i suce porotnike okružnog suda u okrugu, odnosno u gradu Zagrebu bira narodni odbor dotičnog okruga, odnosno grada Zagreba, dok je one okružnih sudova oblasti birao oblasni narodni odbor. Također, predsjednika, suce i suce porotnike kotarskog suda u kotaru, odnosno gradu birao je narodni odbor kotara, odnosno grada (članak 113. stavci 2. i 3.). 
Naposljetku, vrijedi spomenuti da su građani laici sudjelovali i u nekim drugim oblicima suđenja koji su bili uređeni, primjerice, Pravilnikom o pomorskoj arbitraži pri Trgovinskoj komori FNRJ ${ }^{99}$ koji je određivao da arbitri mogu biti jugoslavenski državljani, uz nastojanje da to budu osobe koje su upućene u propise pomorskog prava i prometa, kao i u poslove o pomorskom osiguranju brodova i robe, "u trgovinu pomorskih prijevoza, u brodogradnju i izgradnju brodskih strojeva kao i poslove uvozne i izvozne trgovine” (članak 2. stavci 2.-3.). Slično tome, i Pravilnik o vanjsko-trgovinskoj arbitraži pri Trgovinskoj komori FNRJ ${ }^{100}$ predviđao je da arbitri mogu biti jugoslavenski državljani, i to uz nastojanje da to budu osobe iz najvažnijih grana vanjsko-trgovinske djelatnosti, uključujući i "transportnu, osiguravajuću i posredničku djelatnost" (članak 2. stavci 2.-3.). ${ }^{101}$

\subsection{RAZDOBLJE OD 1954. DO 1963.}

Donošenjem Ustavnog zakona o osnovama društvenog i političkog uređenja Federativne Narodne Republike Jugoslavije i saveznim organima vlasti ${ }^{102}$ iz 1953. participacija građana laika u suđenju važnu ustavnu potvrdu dobila je kroz odredbu članka 2. stavka 2. kojom je propisano da "radni narod vrši vlast i upravlja društvenim poslovima (...) i neposredno putem (...) učešća građana u upravi i u pravosuđu”, kao i kroz odredbu članka 7. stavka 1. podstavka 2. kojom je propisano da se samoupravljanje "radnog naroda u općini, gradu i kotaru sastoji (...) naročito (...) u pravu građana da neposredno učestvuju u vršenju vlasti putem (...) učešća građana u upravi i u pravosuđu". ${ }^{103}$

Na toj osnovi, Zakonom o sudovima ${ }^{104}$ iz 1954. propisano je da za povremenog suca može biti biran državljanin FNRJ s navršenih 27 godina koji nije osuđivan zbog kaznenog djela koje ga čini moralno nepodobnim za obnašanje sudačke dužnosti i koji je sposoban za obnašanje sudačke dužnosti (članak 47.). Iz toga slijedi da je zakonodavac značajno povisio uvjet minimalne dobi u odnosu na prethodno razdoblje i, uz to, uveo još dvije kvalifikacije: moralnu podobnost, koja je postojala onda kada osoba nije bila osuđena zbog kaznenog djela, ali i sposobnost za obnašanje sudačke dužnosti, kod koje nije preciziran način utvrđivanja njezina ispunjenja. Povremene suce okružnog suda birali su narodni odbori kotara i gradova s područja dotičnoga okružnog suda, a prijedlog za njihov izbor podnosila je komisija sastavljena od predstavnika narodnih odbora s područja dotičnoga okružnog suda i predstavnika tijela uprave za pravosudne poslove koji bio i predsjednik te komisije. Povremene suce kotarskog suda birali

99 Službeni list Federativne Narodne Republike Jugoslavije, broj 26/1947.

100 Službeni list Federativne Narodne Republike Jugoslavije, broj 26/1947.

101 U tom smislu, vidi i: Zuglia, S., Sudovi i ostali organi koji učestvuju u vršenju građanskog pravosuđa, Školska knjiga, Zagreb, 1956. str. 33.

102 Službeni list Federativne Narodne Republike Jugoslavije, broj 3/1953.

103 Ustavni zakon Narodne Republike Hrvatske o osnovama društvenog i političkog uređenja i republičkim organima vlasti (Narodne novine, broj 9/1953) sadržavao je identičnu odredbu članka 2. stavka 2. kao i Ustavni zakon iz 1953. Međutim, za razliku od potonjeg Ustavnog zakona, njime je bio korišten pojam sudaca porotnika, i to u odredbi prema kojoj radni "narod u općini, gradu i kotaru vrši vlast i neposredno putem (...) učešća građana u pravosuđu u svojstvu sudaca porotnika” (članak 7. stavak 4.).

104 Službeni list Federativne Narodne Republike Jugoslavije, broj 30/1954. Prema članku 1. tog Zakona, suđenje su vršili redovni, privredni i vojni sudovi, s time da su ustrojstvo i nadležnost privrednih i vojnih sudova bili određeni posebnim zakonom. 
su narodni odbori kotara i gradova, a prijedlog za njihov izbor podnosila je komisija za izbore narodnih odbora nakon pribavljenog mišljenja predsjednika kotarskog suda (članak 49. stavci 4. i 5. i članak 51. stavci 1. i 2.).

Prema Zakoniku o krivičnom postupku ${ }^{105}$ iz 1953., kod suđenja maloljetnicima povremeni suci morali su biti iz redova profesora, učitelja, odgajatelja ili drugih osoba s iskustvom u odgoju maloljetnika (članak 415. stavak 3.), dok je za povremenog suca privrednog suda, u skladu s člankom 28. Zakona o privrednim sudovima ${ }^{106}$ iz 1954. bilo potrebno stručno znanje ili iskustvo, dakako uz uvjete koji se traže i za povremenog suca redovnog suda. Budući da je potonji Zakon predviđao postojanje okružnih privrednih, viših privrednih i Vrhovnoga privrednog suda, vrijedi spomenuti da je povremene suce Vrhovnoga privrednog suda birala Savezna narodna skupština, a povremene suce viših privrednih sudova republičke, odnosno pokrajinske narodne skupštine, dok su prijedlog podnosila nadležna izvršna vijeća ili određeni broj narodnih zastupnika, odnosno odbornika u postupku koji je bio utvrđen poslovnikom o radu predstavničkog tijela. Povremene suce okružnih privrednih sudova birali su narodni odbori kotara i gradova s područja dotičnoga okružnoga privrednog suda, na prijedlog komisije sastavljene od predstavnika narodnih odbora s područja okružnoga privrednog suda i predstavnika tijela uprave za pravosudne poslove koji je ujedno bio i predsjednik te komisije (članci 30.-32.).

Zakonom o vojnim sudovima ${ }^{107}$ iz 1954. predviđeno je da suce porotnike postavlja "Vrhovni komandant oružanih snaga" iz reda generala, admirala, oficira, vojnih službenika i podoficira, uz uvjet navršenih 27 godina, a za suca porotnika upravnog vijeća Vrhovnoga vojnog suda mogao je biti postavljen samo oficir koji je stručan za upravne poslove (članci 23. i 25.). Dodatno, istim Zakonom detaljno je razrađeno iz kojih su vojnih klasa i s kojim kvalifikacijama morali biti suci porotnici radi suđenja u određenim predmetima pred vojnim sudom u prvom stupnju. Tako je propisano, primjerice, da u kaznenim predmetima protiv oficira ili vojnih službenika s oficirskim rangom ili protiv nevojnih osoba suci porotnici moraju biti oficiri ili vojni službenici oficirskog ranga (članak 15. podstavak 2.).

\subsection{RAZDOBLJE OD 1963. DO 1974.}

U Ustavu Socijalističke Federativne Republike Jugoslavije ${ }^{108}$ participacija građana laika u suđenju dobila je još jednu potvrdu, i to u članku 34. stavku 2. točki 2. kojom je određeno da se radi "ostvarivanja društvenog samoupravljanja građaninu (...) zajamčuje (...) pravo da odlučuje o društvenim poslovima (...) kao sudac porotnik”. U skladu s navedenim individualnim pravom, propisano je da u suđenju sudjeluju suci i suci porotnici, s time da je bilo moguće saveznim zakonom propisati da u određenim sudovima i u određenim stvarima u suđenju sudjeluju samo suci. Međutim, potonja ustavna odredba nije zaživjela, nego su suci porotnici

\footnotetext{
105 Službeni list Federativne Narodne Republike Jugoslavije, broj 40/1953.

106 Službeni list Federativne Narodne Republike Jugoslavije, broj 31/1954.

107 Službeni list Federativne Narodne Republike Jugoslavije, broj 52/1954.

108 Službeni list Socijalističke Federativne Republike Jugoslavije, broj 14/1963. Prema članku 132. stavcima 2.-3. tog Ustava, sudski sustav činili su sudovi opće nadležnosti, koje su činili općinski i okružni sudovi, republički vrhovni sudovi i Vrhovni sud Jugoslavije, kao i specijalizirani sudovi, koje su činili privredni i vojni sudovi.
} 
zadržani u svim sudovima (opće nadležnosti, privrednim i vojnim sudovima), u kaznenom i građanskom suđenju, ${ }^{109}$ kao što nije uspjela zaživjeti ni ustavna odredba o mogućnosti zakonskog propisivanja izravnog izbora ${ }^{110}$ sudaca i sudaca porotnika određenih sudova od strane građana, nego je suce, kao i suce porotnike birala skupština odgovarajuće društveno-političke zajednice (članak 137. stavci 1.-3.).

Ustav Socijalističke Republike Hrvatske ${ }^{111}$ iz iste godine također je propisao sudjelovanje u suđenju sudaca i sudaca porotnika, njihovu ravnopravnost u suđenju i mogućnost da se zakonom propiše da u određenim sudovima i u određenim slučajevima u suđenju sudjeluju samo suci. Iako je ustavna mogućnost za zakonsko propisivanje izravnog izbora postojala i na republičkoj razini, suce i suce porotnike općinskih sudova birale su općinske skupštine, dok su za okružne sudove bile nadležne kotarske skupštine (članci 230.-231.). Na tom temelju donesen je republički Zakon o sudovima ${ }^{112}$ u kojemu nisu bile sadržane odredbe u vezi s uvjetima koje su morali ispunjavati suci porotnici, ali je njime propisano da suce i suce porotnike okružnih privrednih sudova, Vrhovnog suda Hrvatske i Višeg privrednog suda bira Republičko vijeće Sabora (članak 23. stavak 3.).

Razrađujući ustavne odredbe o sucima i sucima porotnicima, Osnovni zakon o sudovima opće nadležnosti113 iz 1965. odredio je da za suca porotnika može biti biran punoljetni jugoslavenski državljanin koji je sposoban obnašati sudačku dužnost (članak 41. stavak 1.), ali je posebnim zakonom bilo moguće predvidjeti da za suca porotnika kod suđenja maloljetnicima ili u drugim određenim stvarima može biti birana osoba s potrebnim iskustvom ili stručnom spremom za suce u tim stvarima. Tako je odredbom članka 423. stavka 5. Zakonika o krivičnom postupku ${ }^{114}$ iz 1967. bilo propisano da se kod suđenja maloljetnicima suci porotnici biraju iz redova profesora, učitelja, odgajatelja ili drugih osoba s iskustvom u odgoju maloljetnika (što je ostalo nepromijenjeno od osnovnog teksta tog Zakonika iz 1953.), a odredbom članka 43. Zakona o privrednim sudovima iz $1965 .{ }^{115}$ da za suca porotnika može biti biran punoljetni jugoslavenski državljanin koji je, s obzirom na svoje stručno znanje ili iskustvo, sposoban obnašati sudačku dužnost na tom sudu. Suce porotnike privrednih sudova birala je skupština odgovarajuće društveno-političke zajednice (članak 14.).

Prema Zakonu o vojnim sudovima ${ }^{116}$ suci porotnici mogli su biti postavljeni isključivo iz reda oficira, podoficira i vojnih službenika (članak 31. stavak 2.), čime se, u odnosu na zakonska rješenja iz prethodnog razdoblja, odustalo od zahtjeva za njihovim postavljanjem iz reda

109 Kamhi; Čalija, op. cit. u bilj. 84, str. 22.

110 Ljubanović, op. cit. u bilj. 38, str. 40.

111 Narodne novine, broj 15/1963. Prema članku 227. tog Ustava, sudovi opće nadležnosti bili su općinski, okružni i Vrhovni sud, dok su za suđenje u privrednim sporovima i stvarima od interesa za privredu postojali privredni sudovi i Viši privredni sud.

112 Narodne novine, broj 21/1967.

113 Službeni list Socijalističke Federativne Republike Jugoslavije, broj 7/1965.

114 Službeni list Socijalističke Federativne Republike Jugoslavije, broj 50/1967. Radi lakšeg praćenja brojnih izmjena i dopuna tog Zakonika, a napose imajući u vidu izmjene i dopune po stupanju na snagu Ustava iz 1963., u ovom radu korišten je pročišćeni tekst koji je utvrdila Zakonodavno-pravna komisija Savezne skupštine 9. studenoga 1967. Spomenutim pročišćenim tekstom obuhvaćen je Zakonik o krivičnom postupku (Službeni list Federativne Narodne Republike Jugoslavije, broj 40/1953) i njegove izmjene i dopune objavljene u Službenom listu Federativne Narodne Republike Jugoslavije, broj 52/1959. i 30/1962 i u Službenom listu Socijalističke Federativne Republike Jugoslavije, broj 12/1965 i 23/1967.

115 Službeni list Socijalističke Federativne Republike Jugoslavije, broj 7/1965.

116 Službeni list Socijalističke Federativne Republike Jugoslavije, broj 7/1965. 
generala i admirala te od uvjeta od navršenih 27 godina, ali je zadržano zakonsko rješenje iz 1947. prema kojemu ih na tu dužnost postavlja "vrhovni komandant oružanih snaga" (članak 29.). Tim Zakonom nastavilo se detaljno razrađivati kvalifikacije sudaca porotnika radi suđenja pred vojnim sudom u prvom stupnju. Tako je u nastojanju za uzimanjem u obzir specifične naravi pojedinih predmeta propisano, primjerice, da u kaznenim stvarima protiv maloljetnika suci porotnici moraju biti oficiri ili vojni službenici od VII. do I. klase s iskustvom u odgajanju maloljetnika (članak 18. točka 4.).

\subsection{RAZDOBLJE OD 1974. DO 1990.}

Sljedećim Ustavom Socijalističke Federativne Republike Jugoslavije ${ }^{117}$ (iz 1974.) općenito je određeno da nepovredivu "osnovu položaja i uloge čovjeka čine (...) pravo na samoupravljanje, na temelju kojega svaki radni čovjek, ravnopravno s drugim radnim ljudima (...) ostvaruje vlast i upravlja drugim društvenim poslovima" (odjeljak II. uvodnog dijela). U tom ostvarivanju vlasti, u suđenju su mogli sudjelovati "suci i radni ljudi te građani kao suci, suci porotnici ili porotnici, na način utvrđen zakonom odnosno aktom o ustanovljenju suda”, no zakonom je bilo moguće propisati i da "u određenim sudovima i u određenim stvarima u suđenju sudjeluju samo suci” (članak 229. stavci 1. i 2.). Iz toga slijedi da je na ustavnoj razini utvrđena vrlo široka platforma na kojoj su građani laici mogli sudjelovati u suđenju, a posebno je zanimljivo da se, s obzirom na takvu stipulaciju članka 229. stavka 1., istovremeno omogućilo i prisjedničko ("suci-porotnici"), i porotno suđenje ("porotnici"), i suđenje bez sudjelovanja građana laika ("samo suci"), s time da je potonje moglo biti samo u određenim sudovima i određenim stvarima. Odabir konkretnog oblika participacije građana laika u suđenju, kao i pitanje njihovih kvalifikacija ustavotvorac je prepustio zakonskom uređenju te su, u skladu s Ustavom utvrđenim ovlastima na saveznoj, republičkoj, odnosno pokrajinskoj razini, po donošenju republičkih i pokrajinskih ustava doneseni i republički zakoni o redovnim sudovima, kao i savezni zakoni koji se tiču prava i dužnosti federacije, inter alia, u području uređivanja kaznenog i drugih sudskih postupaka, vojnih sudova i Saveznog suda. Izričajno vrlo slično rješenju koje je predviđao Zakon o privrednim sudovima iz 1965., Ustavom je određeno da suce porotnike bira skupština odgovarajuće društveno-političke zajednice (članak 230. stavak 1.).

Navedene odredbe Ustava SFRJ iz 1974. u neizmijenjenom obliku ugrađene su u Ustav Socijalističke Republike Hrvatske ${ }^{118}$ (u odjeljak II., članak 315. stavak 1. i 2. te članak 316. stavak 1.), a na tom ustavnom temelju donesen je Zakon o redovnim sudovima ${ }^{119}$ iz 1977. Budući da je navedenim Zakonom propisano da u suđenju sudjeluju suci i suci porotnici koji su kod donošenja sudskih odluka ravnopravni (članak 13. stavak 1.), iz toga proizlazi da se zakonodavac odlučio za primjenu prisjedničkog suđenja, ali je zakonom bilo moguće odrediti

117 Službeni list Socijalističke Federativne Republike Jugoslavije, broj 9/1974. Prema člancima 217. i 225. Ustava postojali su (u jedinstvenom sustavu vlasti) redovni sudovi, kao tijela državne vlasti, i samoupravni sudovi, koji su se ustanovljavali kao sudovi udruženog rada, arbitraže, mirovna vijeća, izabrani sudovi i drugi oblici samoupravnih sudova. Identične odredbe bile su sadržane i u člancima 302. i 311. hrvatskog Ustava iz iste godine.

118 Narodne novine, broj 8/1974.

119 Narodne novine, broj 5/1977. Prema tom Zakonu, redovni sudovi bili su općinski, okružni i okružni privredni sudovi te Viši privredni, Upravni i Vrhovni sud Hrvatske (članak 26.). 
da u određenim sudovima i u određenim stvarima u suđenju sudjeluju samo suci (članak 13. stavak 2.). Za suca porotnika mogao je biti biran svaki punoljetni jugoslavenski državljanin koji je moralno-politički podoban i sposoban za obnašanje sudačke dužnosti (članak 99.), a ti uvjeti bili su na snazi sve do 1990. kada je Zakonom o izmjenama i dopunama Zakona o redovnim sudovima ${ }^{120}$ bilo propisano da za suca porotnika može biti biran "punoljetni jugoslavenski državljanin koji je sposoban za obavljanje sudačke dužnosti i po svojim radnim i ljudskim kvalitetama dostojan ugleda sudačke funkcije" (članak 40.). Međutim, s obzirom na to da u praksi nije bilo znanog načina utvrđivanja postojanja takve sposobnosti, ona se nije utvrđivala. ${ }^{121}$

Polazeći od shvaćanja da je kod suđenja maloljetniku nužno iznaći najpogodnije rješenje u okviru zakona, u cilju ispravnog usmjeravanja njegova daljnjeg razvoja ${ }^{122}$ Zakon o krivičnom postupku ${ }^{123}$ iz 1977. zadržao je rješenje iz Zakonika o krivičnom postupku iz 1953. prema kojemu se suci porotnici imaju birati iz redova profesora, učitelja, odgajatelja ili drugih osoba s iskustvom u odgoju maloljetnika (članak 463. stavak 4.), a ti uvjeti ostali su na snazi do prestanka važenja tog Zakona stupanjem na snagu Zakona o kaznenom postupku ${ }^{124}$ iz 1997. Kada je riječ o vojnim sudovima, treba spomenuti da su i u ovom razdoblju zabilježene određene promjene u odnosu na prethodna rješenja, i to ponovno kod redova iz kojih se postavljaju suci porotnici. Naime, prema Zakonu o vojnim sudovima ${ }^{125}$ iz 1977. suci porotnici mogli su biti postavljeni iz redova oficira, mlađih oficira, vojnih službenika, ali i građanskih osoba na službi u oružnim snagama (članak 32. stavak 2.), čime je došlo do širenja kruga osoba koje su mogle biti postavljene na tu dužnost, ali uz zadržavanje zakonske odredbe o kvalifikacijama za suđenje u određenim stvarima u prvom stupnju koju je predstavio raniji zakon iz 1954. Suce porotnike i dalje je, po uzoru na zakonsko rješenje iz 1947., postavljao "Vrhovni komandant oružanih snaga", s time da je Zakon o izmjenama i dopunama Zakona o vojnim sudovima ${ }^{126}$ iz 1982. propisao da ih postavlja Predsjedništvo SFRJ. Navedena zakonska rješenja ostala su na snazi sve do Zakona o stavljanju izvan snage u Republici Hrvatskoj Zakona o vojnim sudovima i Zakona o vojnom tužilaštvu ${ }^{127}$ iz 1991.

Pored toga, suci porotnici sudjelovali su i u suđenju u Saveznom sudu, kao najvišem sudu Federacije, u skladu sa Zakonom o Saveznom sudu ${ }^{128}$ iz 1974. prema kojemu je savezna Skupština za suca porotnika mogla birati punoljetnoga jugoslavenskog državljanina koji je bio "moralno-politički podoban za obavljanje te funkcije” (članak 7. i članak 13. stavak 2.). Iako je Zakonom o izmjenama i dopunama Zakona o Saveznom sudu ${ }^{129}$ iz 1990. umjesto uvjeta mo-

\footnotetext{
120 Narodne novine, broj 16/1990.

121 Ljubanović, op. cit. u bilj. 38, str. 58.

122 Ibid.

123 Službeni list Socijalističke Federativne Republike Jugoslavije, broj 4/1977.

124 Narodne novine, broj 110/1997.

125 Službeni list Socijalističke Federativne Republike Jugoslavije, broj 4/1977.

126 Službeni list Socijalističke Federativne Republike Jugoslavije, broj 13/1982.

127 Narodne novine, broj 53/1991.

128 Službeni list Socijalističke Federativne Republike Jugoslavije, broj 21/1974. Početkom rada tog suda prestali su s radom Vrhovni sud Jugoslavije i Vrhovni privredni sud.

129 Službeni list Socijalističke Federativne Republike Jugoslavije, broj 20/1990.
} 
ralno-političke podobnosti predviđena sposobnost za obnašanje sudačke dužnosti, već 1991. Zakon o Saveznom sudu stavljen je izvan snage. ${ }^{130}$

Imajući u vidu da je ustavotvorac na saveznoj i (hrvatskoj) republičkoj razini predvidio da sudsku funkciju u jedinstvenom sustavu vlasti obavljaju i samoupravni sudovi - kao što su sudovi udruženog rada, arbitraže, mirovna vijeća, izabrani sudovi, ali i drugi oblici samoupravnih sudova - građani laici dobili su znatno šire mogućnosti participacije u odnosu na dotadašnja rješenja. ${ }^{131}$ Tako je savezni Zakon o sudovima udruženog rada ${ }^{132}$ iz 1984. propisao da u suđenju ravnopravno sudjeluju suci te "radnici, drugi radni ljudi i građani kao suci" (članak 14. stavak 3.), a (hrvatski) republički Zakon o sudovima udruženog rada ${ }^{133}$ pobliže odredio uvjete za njihov izbor. Naime, suce suda udruženog rada prema potonjem Zakonu birale su skupštine društveno-političkih zajednica i skupštine samoupravnih interesnih zajednica, a za suca tog suda mogao je biti biran jugoslavenski državljanin koji ima "odgovarajuće iskustvo, stručnost i moralno-političku podobnost potrebne za razrješavanje spornih odnosa iz nadležnosti sudova udruženog rada", dok je za tzv. suca bez svojstva radnika u tom sudu mogao biti biran, i to tek iznimno, i sudac redovnog suda kojemu tim izborom nije prestala dužnost suca redovnog suda (članci 8., 36. i 37.). Spomenuti republički Zakon bio je na snazi do 1990., sukladno Zakonu o prestanku rada sudova udruženog rada, ${ }^{134}$ a savezni Zakon o sudovima udruženog rada stavljen je izvan snage $1991 .{ }^{135}$ Iako bi se u kontekstu samoupravnih sudova moglo izdvojiti i mirovna vijeća koja su predviđena Zakonom o mirovnim vijećima ${ }^{136}$ u cilju posredovanja u sporovima radi mirenja ili rješavanja pojedinih sporova o pravima kojima "radni ljudi i građani” slobodno raspolažu (članak 1.), valjalo bi napomenuti da profesionalni suci u tom samoupravnom sudu nisu spomenuti, budući da su kao članovi tog vijeća navedeni "radni ljudi i građani kao suci" (članak 7.). S obzirom na to da je određeno da suce-članove biraju "radni ljudi i građani”, i to između jugoslavenskih punoljetnih državljana koji uživaju društveni ugled u sredini u kojoj žive i rade (članak 13. stavci 1. i 3.), proizlazi da je kod tog oblika samoupravnih sudova u cijelosti prevladao laički element. Odredbe tog Zakona, zanimljivo, nikada nisu stavljene izvan snage, niti su ikad izmijenjene i/ili dopunjene. ${ }^{137}$

130 Zakon o stavljanju izvan snage u Republici Hrvatskoj Zakona o pomilovanju, Zakona o Saveznom sudu, Zakona o sudovima udruženog rada, Zakona o Saveznom javnom pravobranilaštvu, Zakona o postupku za upis u sudski registar, Zakona o saveznim sudskim taksama, Zakona o društvenom pravobraniocu samoupravljanja i Zakona o Saveznom društvenom pravobraniocu samoupravljanja (Narodne novine, broj 53/1991).

131 Stevanović, Č., Neka pitanja u vezi sa učešćem građana u suđenju, Zbornik radova Pravnog fakulteta u Nišu, [s. n.], br. 15, 1975., str. 71.

132 Službeni list Socijalističke Federativne Republike Jugoslavije, broj 38/1984. Iako je pod istim nazivom postojao i zakon koji je donesen 1974. (Službeni list Socijalističke Federativne Republike Jugoslavije, broj 24/1974.) iz njega se nije moglo sasvim jasno razabrati tko sve ima pravo sudjelovati u suđenju pa je spomenuti nedostatak ispravljen novim zakonom pod istim nazivom iz 1984., ali i republičkim zakonima o sudovima udruženog rada.

133 Narodne novine, broj 26/1976.

134 Narodne novine, broj 53/1990.

135 Zakon o stavljanju izvan snage u Republici Hrvatskoj Zakona o pomilovanju, Zakona o Saveznom sudu, Zakona o sudovima udruženog rada, Zakona o Saveznom javnom pravobranilaštvu, Zakona o postupku za upis u sudski registar, Zakona o saveznim sudskim taksama, Zakona o društvenom pravobraniocu samoupravljanja i Zakona o Saveznom društvenom pravobraniocu samoupravljanja (Narodne novine, broj 53/1991).

136 Narodne novine, broj 14/1978.

137 U tom smislu, vidi i, npr.: Triva, S.; Dika, M., Građansko parnično procesno pravo, Narodne novine, Zagreb, 2004., str. 923. 


\subsection{RAZDOBLJE OD 1990. DO DANAS}

U članku 118. Ustava Republike Hrvatske ${ }^{138}$ iz 1990. propisano je da u suđenju sudjeluju i suci porotnici, u skladu sa zakonom, a takvo ustavno rješenje zadržano je do danas. Na toj ustavnoj osnovi kvalifikacije za suca porotnika najprije su bile uređene izloženim rješenjem prema Zakonu o redovnim sudovima iz 1977. koji je ostao na snazi do početka primjene Zakona o sudovima ${ }^{139}$ iz 1994. Potonjim Zakonom za imenovanje suca porotnika propisana su tri uvjeta: uz punoljetnost, zahtijevalo se hrvatsko državljanstvo i dostojnost obnašanja dužnosti suca porotnika (članak 68.). No, s obzirom na to da je istim člankom predviđeno i da se odredbe tog Zakona o sucima mutatis mutandis primjenjuju i na suce porotnike, ako nešto drugo nije uređeno zakonom, uz spomenuta tri uvjeta za suca porotnika zahtijevalo se i da ne pripada nijednoj političkoj stranci i ne sudjeluje u njezinim aktivnostima ${ }^{140}$ (članak 60.). Pored toga, na njega je primjenjivana zabrana obavljanja odvjetničke ili javnobilježničke službe i poslova članova upravnih i nadzornih odbora trgovačkih društava ili druge pravne osobe "koja je osnovana radi stjecanja dobiti" ${ }^{141} \mathrm{i}$ zabrana obavljanja neke druge službe ili posla "koji bi mogli utjecati na njegovu samostalnost, nepristranost ili neovisnost" ili dovesti do umanjenja njegova društvenog ugleda ili su inače inkompatibilni s obnašanjem sudačke dužnosti (članak 61.). Usto, imajući u vidu izričitu ustavnu i zakonsku odredbu o gornjoj dobnoj granici (70 godina života) za suce, ${ }^{142}$ taj uvjet primijenjen je i na suce porotnike. Iako je Zakon o sudovima ${ }^{143}$ iz 2005. zadržao uvjete punoljetnosti, hrvatskog državljanstva i dostojnosti obnašanja dužnosti suca porotnika (članak 131.), došlo je do ispuštanja odredbe o odgovarajućoj primjeni odredbi tog Zakona o sucima. Ipak, nakon što je navedena odredba vraćena Zakonom o izmjenama i dopunama Zakona o sudovima ${ }^{144}$ iz 2007. (članak 8.), za imenovanje suca porotnika ponovno

138 Narodne novine, broj 56/1990. Iako je izvorni tekst Ustava iz 1990. odredbu o sucima porotnicima sadržavao u članku 118. nakon izmjena i dopuna ustavnih odredbi i objavljenih pročišćenih tekstova izmijenjena je enumeracija odredbi pa je u važećem ustavnom tekstu odredba o sucima porotnicima sadržana u članku 121. stavku 2.

139 Narodne novine, broj 3/1994. Navedeni Zakon propisao je da sudbenu vlast obavljaju općinski, županijski, vojni i trgovački sudovi, Visoki trgovački sud, Upravni sud, da je Vrhovni sud najviši sud te da se općinski i kotarski (okružni) sudovi ustanovljuju na područjima s posebnim samoupravnim statutom, dok su se posebnim zakonom za određena pravna područja mogli ustanoviti posebni sudovi (članak 13.). Za imenovanje sudaca porotnika općinskih, trgovačkih i županijskih sudova bila je nadležna županijska skupština, odnosno Gradska skupština Grada Zagreba, s time da su prijedlog mogli uputiti općinsko, odnosno gradsko vijeće, sindikati, udruženja poslodavaca i gospodarska komora, dok je imenovanje sudaca porotnika ostalih sudova stavljeno u nadležnost Zastupničkog doma Sabora Republike Hrvatske, na prijedlog ministra pravosuđa (članak 70.).

140 Za razliku od izvornog zakonskog teksta iz 1994. kojim je bila propisana zabrana sudjelovanja u stranačkim aktivnostima, Zakonom o izmjenama i dopunama Zakona o sudovima (Narodne novine, broj 17/2004) propisana je zabrana bavljenja političkom djelatnošću.

141 Citirane riječi dopunile su izvorni zakonski tekst iz 1994. na temelju članka 17. Zakona o izmjenama i dopunama Zakona o sudovima (Narodne novine, broj 100/1996). Međutim, iste riječi ispuštene su već u sljedećem Zakonu o sudovima iz 2005. (vidi infra bilj. 143).

142 Vidi: članak 58. Promjene Ustava Republike Hrvatske (Narodne novine, broj 113/2000) i članak 35. Zakona o izmjenama i dopunama Zakona o sudovima (Narodne novine, broj 129/2000), ali i ranije: članak 16. Zakona o izmjenama i dopunama Zakona o sudovima (Narodne novine, broj 100/1996) i članak 1. Zakona o dopuni Zakona o sudovima (Narodne novine, broj 131/1997).

143 Narodne novine, broj 150/2005. Navedenim Zakonom propisano je da sudbenu vlast obavljaju redovni (općinski, županijski sudovi i Vrhovni sud) i specijalizirani sudovi (prekršajni i trgovački sudovi, Visoki prekršajni, Visoki trgovački i Upravni sud) te da je zakonom s obzirom na stvarnu nadležnost ili za određena pravna područja moguće ustanoviti i druge redovne $i$ specijalizirane sudove (članak 13.). Za imenovanje sudaca porotnika općinskih, trgovačkih i županijskih sudova propisana je nadležnost županijske skupštine, odnosno Gradske skupštine Grada Zagreba, s time da su za podnošenje prijedloga ovlaštena općinska, odnosno gradska vijeća, sindikati, udruženja poslodavaca i gospodarska komora, dok je imenovanje sudaca porotnika Visokoga trgovačkog suda propisna nadležnost Hrvatskoga sabora po prijedlogu ministra pravosuđa (članak 133.). 
je, uz punoljetnost, državljanstvo i dostojnost, trebalo ispuniti sve prethodno spomenute kvalifikacije koje su se primjenjivale i na suce, a navedena zakonska rješenja zadržana su i nakon donošenja važećeg Zakona o sudovima ${ }^{145}$ iz 2013. te su na snazi i danas.

Kad je riječ o suđenju maloljetnicima, kvalifikacije za suca porotnika iz ranijih razdoblja ostale su u bitnosti iste. Naime, otkako je Zakonik o krivičnom postupku iz 1953. odredio da se suci porotnici biraju iz redova profesora, učitelja, odgajatelja ili drugih osoba s iskustvom u odgoju maloljetnika, takvo rješenje najprije je preuzeo Zakon o krivičnom postupku iz 1977. koji je važio sve do stupanja na snagu Zakona o kaznenom postupku iz 1997. Nakon što je Zakon o sudovima za mladež ${ }^{146}$ iz 1997. (članak 40. stavak 2.) preuzeo prethodno zakonsko rješenje uz tek manje izmjene (umjesto pojma maloljetnika korišten je pojam mladih osoba), važeći Zakon o sudovima za mladež ${ }^{147}$ iz 2011. preuzeo je gotovo identične kvalifikacije, s tom razlikom što je umjesto iskustva u odgoju mladih osoba predviđeno "radno iskustvo" u "stručnom odgojnom radu" s mladim osobama (članak 41. stavak 2.).

Zakonom o službi u oružanim snagama Republike Hrvatske ${ }^{148}$ iz 2002. također je propisano sudjelovanje sudaca porotnika, u vojnostegovnim sudovima (članak 79. stavak. 1.), no njime nisu bile uređene kvalifikacije za suce porotnike, već je to učinjeno Pravilnikom o vojnoj stezi ${ }^{149}$ kojim se zahtijevalo da moraju biti jednakog ili višega osobnog čina od osobnog čina okrivljenika, a određivao ih je predsjednik tog suda (članak 65. stavci 2.-3.). Na zakonskoj razini uvjeti su nešto drugačije uređeni važećim Zakonom o službi u Oružanim snagama Republike Hrvatske ${ }^{150}$ kojim je propisano da sudac porotnik ima "osobni čin generala/admirala" (članak 190. stavak 2.), a imenuje ga Predsjednik Republike po prijedlogu koji mu uputi načelnik Glavnog stožera uz pribavljenu suglasnost ministra obrane.

Naposljetku, iako je kroz prizmu mogućnosti participacije građana laika u suđenju moguće izdvojiti i arbitražni sud, valjalo bi napomenuti da je riječ o sudu u kojemu suđenje obavljaju one "osobe kojima investituru za suđenje daju stranke svojim ugovorom - arbitri (izbrani suci)"151. U tom smislu, važeći Zakon o arbitraži ${ }^{152}$ iz 2002. predviđa slobodu sporazumijevanja stranaka o postupku imenovanja arbitara (uz uvjet da se pridržavaju odredbi tog Zakona) te nitko ne može biti spriječen da bude arbitar zbog svojeg državljanstva (osim u slučaju drugači-

145 Narodne novine, broj 28/2013, 33/2015, 82/2015, 82/2016, 67/2018. Važeći zakon predviđa da sudbenu vlast obavljaju redovni (općinski i županijski sudovi) i specijalizirani (trgovački i upravni sudovi, Visoki trgovački, Visoki upravni, Visoki prekršajni i Visoki kazneni sud) te Vrhovni sud, uz mogućnost da se zakonom, s obzirom na stvarnu nadležnost ili za određena pravna područja, ustanove i drugi redovni i specijalizirani sudovi te da se zakonom odredi nadležnost jednog ili više sudova radi odlučivanja u određenoj vrsti predmeta "za područje jednog, više ili svih sudova te vrste" (članak 14.). Za imenovanje sudaca porotnika općinskih i županijskih sudova nadležna je županijska skupština, odnosno Gradska skupština Grada Zagreba, s time da su prijedloge ovlašteni uputiti općinsko, odnosno gradsko vijeće, sindikati, udruge poslodavaca i gospodarska komora (članak 119. stavak 1.).

146 Narodne novine, broj 111/1997, 27/1998, 12/2002, 84/2011.

147 Narodne novine, broj 84/2011, 143/2012, 148/2013, 56/2015.

148 Narodne novine, broj 33/2002, 58/2002, 175/2003, 136/2004, 76/2007, 88/2009, 124/2009, 73/2013.

149 Narodne novine, broj 95/2003. Sličnu odredbu sadržavao je i sljedeći Pravilnik o vojnoj stezi (Narodne novine, broj 3/2008), s tom razlikom što je umjesto pojma okrivljenika koristio pojam stranke (članak 47. stavak 3.).

150 Narodne novine, broj 73/2013, 75/2015, 50/2016, 30/2018.

151 Triva; Dika, op. cit. u bilj. 137, str. 852.

152 Narodne novine, broj 88/2001. 
jeg sporazuma stranaka), a suce hrvatskih sudova stranke mogu izabrati samo za predsjednika arbitražnog vijeća ili za arbitra pojedinca (članak 10. stavci 1.-3.).

\section{MOGUĆNOSTI UNAPRJEĐENJA VAŽEĆIH RJEŠENJA}

Iz dosad izloženog slijedi da je u oblikovanju važećih odredbi kojima se uređuje materija kvalifikacija za participaciju građana laika u prisjedničkom suđenju kao sudaca porotnika moguće primijetiti utjecaj ranijih zakonskih rješenja, napose iz razdoblja od 1945. do 1954., ali i da je, baš kao i u prethodno opisanim razdobljima, ostao stanoviti prostor za unaprjeđenje pojedinih rješenja. Naime, iako se zakonodavac odlučio za relativno mali broj kvalifikacija za participaciju građana laika (punoljetnost, hrvatsko državljanstvo i dostojnost te opisane kvalifikacije koje se odnose na suce) na temelju Zakona o sudovima iz 2013., čime je omogućena participacija vrlo širokoga kruga građana, istovremeno je korištenjem općenitih formulacija pri propisivanju pojedinih kvalifikacija, posebice dostojnosti obnašanja dužnosti suca porotnika, otvorena mogućnost različitog tumačenja načina utvrđivanja njezina ispunjenja, a time i neujednačene primjene u praksi. Kao što je prethodno utvrđeno u ovom radu, riječ je o pristupu zakonodavca koji je redovito korišten pri propisivanju kvalifikacija za participaciju građana laika u prisjedničkom suđenju kao sudaca porotnika još od 1954. nadalje (1965., 1977., 1990., 1994., 2005. i 2013.).

O pojmu dostojnosti u nekoliko svojih odluka, odnosno rješenja očitovao se Ustavni sud Republike Hrvatske držeći da je u biti riječ o pravnom standardu, s interpretacijom ustanovljenim općeprihvaćenim značenjem i sadržajem te s obvezujućim djelovanjem za sve one koji ga imaju primijeniti, kojem je već po sâmoj naravi stvari onemogućeno da ispunjava zahtjeve za preciznim određenjem pravnog pojma pa se, stoga, u svakom pojedinom slučaju pažljivo procjenjuju svi razlozi i okolnosti primjene tog instituta (dostojnosti). ${ }^{153} \mathrm{U}$ tom smislu, dostojnost nije dostatno poistovjetiti s pojmom nekažnjavanja ili pravnim posljedicama osude u smislu kaznenog prava, s obzirom na to da sadrži cjelinu moralnih odlika u koju bi, među ostalim, valjalo ubrojiti krjepost, čestitost i poštenje, kao i odlike poput predanosti dužnostima, savjesnosti, discipliniranosti itd. ${ }^{154} \mathrm{~S}$ druge strane, imajući u vidu pojedine primjere iz prakse, ${ }^{155}$ doima se da ipak postoji prostor za stanovita unaprjeđenja, i to kroz mogućnost dopune važećega zakonskog rješenja propisivanjem načina utvrđivanja njihova ispunjenja i dokaza koje bi zainteresirani kandidati za suca porotnika morali dostaviti već pri podnošenju prijave. Tako bi se, primjerice, u okviru članka 117. (ili 119.) važećeg Zakona o sudovima, mogla propisati

153 Vidi npr.: Odluka Ustavnog suda Republike Hrvatske broj: U-III-706/2003 od 8. srpnja 2003. (Narodne novine, broj 120/2003), Odluka Ustavnog suda Republike Hrvatske broj: U-III-2916/2007 od 16. listopada 2012. (URL=https://www.usud.hr/. Pristupljeno: 10. ožujka 2019.), Rješenje Ustavnog suda Republike Hrvatske broj: U-I-1080/2002 i dr. od 12. ožujka 2008. (Narodne novine, broj 50/2008) itd.

154 Rješenje Ustavnog suda Republike Hrvatske broj: U-I-337/1994 od 5. srpnja 1995. (Narodne novine, broj 49/1995).

155 Tako se u medijima moglo pročitati, primjerice, da je među predloženim kandidatima za suce porotnike znalo biti i osoba koje pripadaju određenoj političkoj stranci ili da se bave političkom djelatnošću, osoba za koje se sumnjalo da se nalaze u sukobu interesa, pa čak i da je bilo onih protiv kojih je pokrenut kazneni postupak. Vidi npr. [s. n.] Sude nam političari s kaznenim prijavama. URL=https://www.jutarnji.hr/arhiva/sude-nam-politicari-s-kaznenim-prijavama-nije-uslo/4008990/amp. Pristupljeno: 10. ožujka 2019. Usto, vidi: [s. n.] Šeks opet odbio suce porotnike. URL=https://www.jutarnji.hr/arhiva/seks-opetodbio-suce-porotnike/3389516/. Pristupljeno: 10. ožujka 2019. 
obveza dostavljanja uvjerenja da se ne vodi kazneni postupak, preslike osobne iskaznice (kao dokaza hrvatskog državljanstva i godina života), kao i vlastoručno potpisane izjave kandidata da nije član političke stranke i da se ne bavi političkom djelatnošću te da ne obavlja službu ili poslove koji su navedeni u članku 91. stavku 2. i 3. Zakona o sudovima, i to napose s obzirom na brojne primjere javnih poziva za podnošenje prijava za kandidate za suce porotnike u kojima se ističe tek zahtjev da kandidati vlastoručno potpišu obrazac svoje izjave s određenim sadržajem ${ }^{156}$ i zatim je dostave na određenu adresu.

Ujedno, vodeći se za prethodno spomenutim shvaćanjem pojma dostojnosti kao ukupnosti moralnih odlika, valjalo bi razmotriti mogućnost da se u članku 119. izrijekom propiše obveza nadležnih tijela u postupku imenovanja sudaca porotnika da pri utvrđivanju ispunjenja kvalifikacije dostojnosti obnašanja dužnosti sudaca porotnika posebice povedu računa o cjelini moralnih odlika predloženih kandidata, uz egzemplifikativno navođenje niza spomenutih odlika poput predanosti dužnostima, čestitosti, savjesnosti, discipliniranosti itd., kako bi se ukazalo na višeslojnost pojma dostojnosti i ujedno dalo smjernice pri pojašnjenju njegova značenja, doprinoseći ujednačenoj interpretaciji. Naime, pravila nomotehnike nalažu da pravne "formulacije u tekstu pravnih propisa ne trpe dvosmislenost upotrijebljenih izraza", ${ }^{157}$ zbog čega bi u svaki pravni propis valjalo ugraditi "onoliko jezičnih izraza koliko je najmanje nužno da bi se shvatila misao donosioca", ${ }^{158}$ pa tako i što točnije odredilo značenje korištenog pojma.

Pored toga, imajući u vidu i odredbe o zastupljenosti pripadnika nacionalnih manjina na temelju članka 7. točke 8. i članka 22. stavka 2. Ustavnog zakona o pravima nacionalnih manjina ${ }^{159}$ te članka 50. stavka 1 . Zakona o Državnom sudbenom vijeću, ${ }^{160}$ ali i odredbe o uravnoteženoj zastupljenosti obaju spolova na temelju članka 12. stavka 4. Zakona o ravnopravnosti spolova, ${ }^{161}$ u članku 119. Zakona o sudovima izrijekom bi mogla biti propisana i obveza nadležnih tijela da u postupku imenovanja sudaca porotnika povedu računa i o zastupljenosti pripadnika nacionalnih manjina, i o uravnoteženoj zastupljenosti obaju spolova. Takvim bi se pristupom omogućilo da izložene obveze spomenutih tijela u tom postupku sustavno, izrijekom i na jednom mjestu budu uređene, čime bi se zacijelo doprinijelo i njihovu pravilnijem oživotvorenju, napose s obzirom na pojedine primjere zaključaka nadležnih tijela o pokretanju postupka za imenovanje sudaca porotnika. ${ }^{162}$

\footnotetext{
156 U tom obrascu izjave uobičajeno se uz navođenje osobnih podataka ističe podnositeljevo prihvaćanje kandidature te navodi da se u svrhu provedbe postupka imenovanja pod kaznenom i materijalnom odgovornošću izjavljuje da se protiv njega ne vodi kazneni postupak, odnosno da ne postoje drugi razlozi zbog kojih taj podnositelj ne bi bio dostojan obnašanja dužnosti suca porotnika, da nije član nijedne političke stranke i da se ne bavi političkom djelatnošću. Vidi npr.: URL=http://www.gorica.hr/ dokumenti/izjava-porotnici.doc, pristupljeno: 10. ožujka 2019. i URL= http://gospic.hr/file/2018/09/Izjava-suci-porotnici. docx. Pristupljeno: 10. ožujka 2019.

157 Borković, I., Postupak i tehnika izrade pravnih propisa, Informator, Zagreb, 1987., str. 112.

158 Ibid.

159 Narodne novine, broj 155/2002, 47/2010, 80/2010, 93/2011, 93/2011

160 Narodne novine, broj 116/2010, 57/2011, 130/2011, 13/2013, 28/2013, 82/2015, 67/2018.

161 Narodne novine, broj 82/2008,138/2012, 69/2017.

162 Vidi npr.: URL=http://opcina-vladislavci.hr/wp-content/uploads/2018/09/Imenovanje-sudaca-porotnika-Opcinskog-suda-uOsijeku.pdf, pristupljeno 10. ožujka 2019. U tom primjeru zaključka o pokretanju postupka za imenovanje sudaca porotnika istaknuto je da će se povesti računa o zastupljenosti pripadnika nacionalnih manjina, ali ne i o uravnoteženoj zastupljenosti obaju spolova, iako to nesporno proizlazi iz Zakona o ravnopravnosti spolova.
} 
Nadalje, iako je Zakonom o sudovima u članku 118. stavku 2. predviđeno da se odredbe tog Zakona koje se odnose na suce "shodno (...) primjenjuju i na suce porotnike, ako zakonom nije drukčije određeno” - čime je zakonodavac u nastojanju za dosljednošću normiranja korištenjem riječi "shodno" posegnuo za primjenom analogije kao sredstva pravne tehnike - pojedini primjeri javnih poziva za podnošenje prijava za kandidate za suce porotnike i obrazloženja uz prijedlog zaključka o utvrđivanju prijedloga za imenovanje sudaca porotnika otkrivaju da se u njima izrijekom ne navode sve propisane kvalifikacije prema članku 118. stavku 2., nego tek neke od njih. ${ }^{163}$ Zbog toga bi bilo korisno umjesto važeće formulacije izrijekom navesti prethodno opisane kvalifikacije koje se odnose na suce iz članka 90. stavka 1. i članka 91. stavaka 2. i 3. Zakona o sudovima, ali i kvalifikaciju iz članka 120. stavka 2. podstavka 5. Ustava Republike Hrvatske o gornjoj dobnoj granici od 70 godina života.

Isto tako, određene nedostatke moglo bi se pripisati i Zakonu o sudovima za mladež koji, za razliku od prethodnih rješenja, više ne sadrži općeniti pojam iskustva, nego radnog iskustva u stručnom odgojnom radu s mladim osobama, ali pobliže ne određuje razdoblje iskustva, kao ni način utvrđivanja te kvalifikacije, iako primjeri iz prakse i ovdje otkrivaju prostor za stanovita unaprjeđenja kroz dopunu važećeg rješenja propisivanjem načina utvrđivanja ispunjenja uvjeta i dokaza koji se moraju dostaviti već pri podnošenju prijave. Tako bi se, primjerice, u članku 41. Zakona o sudovima za mladež moglo propisati minimalni broj godina radnog iskustva u stručnom odgojnom radu s mladim osobama (npr. najmanje pet godina) i obvezu kandidata da pri podnošenju prijave dostave dokaz o radnom iskustvu u struci, dok pojedini stručnjaci ukazuju i na potrebu uvođenja nekih dodatnih mehanizama s obzirom na specifičnost materije. ${ }^{164}$

Razmatrajući ove mogućnosti unaprjeđenja važećih zakonskih rješenja na izloženi način, posebno bi valjalo imati u vidu načelo pravne sigurnosti te pravne izvjesnosti i dosljednosti pri oblikovanju konkretnih odredbi koje moraju imati jasan stil, jednostavne riječi, biti precizne, ali i razvidne izraženim intencijama donositelja propisa, kao što to traže Jedinstvena metodološko-nomotehnička pravila za izradu akata koje donosi Hrvatski sabor ${ }^{165}$ kojima se nastoji osigurati "jedinstvena metodologija, pravno usuglašen i nomotehnički ujednačen izričaj u aktima Hrvatskoga sabora" ${ }^{166}$ u cilju otklanjanja eventualnih nedosljednosti, odnosno dvojbi u tekstu propisa, ali i u njegovoj primjeni. Štoviše, imajući u vidu da je u članku 174. stavku 5. Poslovnika Hrvatskoga sabora ${ }^{167}$ propisano da tekst zakonskog prijedloga "mora biti izrađen u skladu s jedinstvenim metodološko-nomotehničkim pravilima za izradu akata koja donosi Sabor", jasnoća stila, kao i jednostavnost korištenih riječi te preciznost i razvidno izražene intencije zakonodavca trebale bi biti sadržane već u tekstu zakonskog prijedloga, pri pokretanju zakonodavnog postupka. Za time bi se, dakako, valjalo voditi i u perspektivi mogućih una-

163 Vidi npr.: URL=http://www.medjimurska-zupanija.hr/images/sjednice-skupstine-2013/3/25.pdf. Pristupljeno 10. ožujka 2019., URL=http://novska.hr/hr/on-line-vijesti/javni-poziv---prijedlog-za-imenovanje-sudaca-porotnika-zupaniskog-suda,4589.html. Pristupljeno 10. ožujka 2019. ili URL=http://www.split.hr/lgs.axd?t=16\&id=22693. Pristupljeno 10. ožujka 2019.

164 Tako, primjerice, Petö Kujundžić navodi da bi valjalo predvidjeti internu provjeru sudaca porotnika na sudu i uvesti psihološko testiranje u cilju utvrđivanja njihove stabilnosti, kao i obnovu licence svakih godinu dana te voditi bazu podataka "da se ne dogodi da je porotnik čovjek osuđen za djelo na štetu djece”. Strižić, Z.; Jurasić, D., Bludničio nad djetetom, a i dalje je u vijeću koje sudi zlostavljačima. URL=https://www.vecernji.hr/vijesti/bludnicio-nad-djetetom-a-i-dalje-je-u-vijecu-koje-sudizlostavljacima-239586. Pristupljeno: 10. ožujka 2019.

165 Narodne novine, broj 74/2015.

166 Vidi pobliže: Struić, G., Vjerodostojno tumačenje zakona u hrvatskom parlamentarnom pravu od 1947. do danas, Hrvatska i komparativna javna uprava, god. 16, br. 3, 2016., str. 582. 
prjeđenja važećih rješenja koja su izložena u ovom radu, ali i općenito, pri izradi svih drugih propisa i akata koji se uvrštavaju u legislativni proces.

\section{ZAKLJUČNA RAZMATRANJA}

Polazeći od toga da se sudjelovanje građana u postupku donošenja odluka ne oživotvoruje samo u zakonodavnoj i izvršnoj, nego i sudbenoj vlasti, u radu se nastojalo pobliže razmotriti pitanje kvalifikacija građana laika za njihovo sudjelovanje u suđenju. Pritom je istaknuto da propisivanje pojedinih kvalifikacija, a posebice njihova povećeg broja, značajno može utjecati na mogućnost participacije građana laika u suđenju, ograničavajući broj onih koji tim uvjetima mogu udovoljiti i istovremeno smanjujući mogućnost ostvarivanja značajnih uloga participacije koje ne sadrže samo vitalni imperativ suvremene ustavno-demokratske države za demokratizacijom pravosuđa, nego i važnu edukativnu i integrativnu komponentu. Uvažavajući okolnost da su u pojedinim razdobljima hrvatske povijesti građani laici mogli sudjelovati najprije u porotnom, a zatim u prisjedničkom suđenju, u nastojanju za cjelovitim i sustavnim pristupom ovoj materiji u radu je izložen način pravnog uređenja kvalifikacija građana laika u razdoblju od 1848. do 2018. u cilju istraživanja mogućeg utjecaja ranijih hrvatskih zakonskih rješenja na oblikovanje važećih odredbi kojima se uređuje ta materija, ali i postojanja prostora za eventualno unaprjeđenje nekih od važećih rješenja.

Uvidom u relevantne propise kojima je bilo uređeno porotno suđenje na području današnje Hrvatske u 19. stoljeću, ali i druge dostupne izvore o porotnom suđenju u tom razdoblju, najprije je utvrđeno da su se na području današnje Hrvatske u bitnosti poklapale kvalifikacije za porotnika i razlozi zbog kojih pojedine osobe nisu mogle obnašati porotničku dužnost. Izuzevši Privrĕmeni zakon o štampi od 9. svibnja 1849. godine u kojemu nisu bile sadržane odredbe o kvalifikacijama za porotničku dužnost, kao ni razlozi nemogućnosti obnašanja porotničke dužnosti, ostali propisi detaljno su ih uređivali po uzoru na austrijska pravna rješenja te materije, a ona su se u nemalom dijelu poklapala s francuskim pravnim rješenjima iz 19. stoljeća u pogledu kvalifikacija koje se tiču muškog spola, minimalne dobi, državljanstva, poznavanja čitanja i pisanja, ali i isključenja zbog postojanja moralnih i imovinskih razloga te razloga nespojivosti dužnosti. Takvim pristupom značajno je ograničen broj onih koji tim uvjetima mogu udovoljiti, što je istovremeno rezultiralo razmjerno malom mogućnošću ostvarivanja participacije građana laika, i to sve do 1929. kada je porotno suđenje napušteno stavljanjem suđenja $\mathrm{u}$ isključivu nadležnost sudaca profesionalaca do uvođenja prisjedničkog suđenja u hrvatsko zakonodavstvo 1945. godine.

U formativnom razdoblju izgradnje institucija državne vlasti i prava zakonodavac je najprije ostavio vrlo široku mogućnost participacije u suđenju određivanjem da za suca porotnika može biti biran svaki građanin s biračkim pravom (1945.), odnosno građanin kojemu nije oduzeto neko političko ili građansko pravo, ako je mogao izvršavati zadaće sudova u vršenju pravosuđa (1946.), iako u potonjem slučaju nije jasan način utvrđivanja ispunjenja tog uvjeta. U odnosu na razdoblje porotničkog suđenja odustalo se od propisivanja brojnih kvalifikacija, kao i određivanja skupina osoba koje nisu mogle obnašati porotničku dužnost zbog moralnih i imovinskih razloga ili, pak, razloga nespojivosti dužnosti, što bi se zacijelo moglo pripisati snažnom nastojanju zakonodavca 
za demokratizacijom i podruštvljavanjem sudbene vlasti nakon Drugoga svjetskog rata. Budući da čak ni profesionalni sudac u razdoblju od 1945. do 1954. nije morao biti diplomirani pravnik (osim sudaca vojnog suda), s obzirom na to da za njegov izbor nije propisan uvjet završenoga pravnog fakulteta, valjalo bi zaključiti da je u tom razdoblju posve dominirao laički element te da je od nekadašnjih kvalifikacija građana laika za sudjelovanje u hrvatskom porotnom suđenju preuzeto samo državljanstvo i minimalna dob, koji su se zahtijevali i u francuskim i austrijskim pravnim rješenjima iz 19. stoljeća, a potonje dvije kvalifikacije zahtijevaju se i danas.

U razdoblju od 1954. do 1963. došlo je do značajnijeg povisivanja uvjeta minimalne dobi (s 18 na 27), a pored državljanstva predviđene su još dvije kvalifikacije: građanin laik nije smio biti osuđen zbog kaznenog djela koje ga je činilo moralno nepodobnim te je morao biti sposoban za obnašanje sudačke dužnosti. Budući da se zakonodavac odlučio koristiti općenite formulacije u propisivanju potonjih kvalifikacija, propuštajući precizirati način njihova ispunjenja, takav pristup otvarao je mogućnost različite interpretacije, a time i neujednačene primjene. Otada pa nadalje zakonodavac se odlučuje upravo za takav, općenit pristup u formulaciji spomenutih kvalifikacija pa je - pored uvjeta državljanstva i punoljetnosti - određivao da za suca porotnika može biti biran onaj koji je: sposoban obnašati sudačku dužnost (1965.), moralno-politički podoban i sposoban za obnašanje sudačke dužnosti (1977.), sposoban za obnašanje sudačke dužnosti i po svojim radnim i ljudskim kvalitetama dostojan ugleda sudačke funkcije (1990.) i dostojan obnašanja dužnosti suca porotnika (1994.), a potonji izraz koristi i važeći Zakon o sudovima. Iako se o pojmu dostojnosti očitovao i Ustavni sud Republike Hrvatske, smatrajući da je po naravi stvari onemogućeno da taj pravni standard ispunjava zahtjeve za preciznim određenjem pravnog pojma, $u$ radu je ukazano na pojedine primjere iz prakse zbog kojih vrijedi razmotriti mogućnost dopune važećeg rješenja propisivanjem načina utvrđivanja ispunjenja te kvalifikacije i dokaza koje svaki kandidat za suca porotnika mora dostaviti već pri podnošenju prijave. Pritom je ukazano na mogućnost izričitog propisivanja obveze nadležnih tijela u postupku imenovanja sudaca porotnika da povedu računa o različitim moralnim odlikama kandidata, uz egzemplifikativno navođenje niza tih odlika poput predanosti dužnostima, čestitosti, savjesnosti, discipliniranosti itd., ali i da pritom povedu računa i o zastupljenosti pripadnika nacionalnih manjina i uravnoteženoj zastupljenosti oba spola.

Za razliku od načina pravnog uređenja spomenutih triju kvalifikacija, kod kojega je očit utjecaj ranijih zakonskih rješenja na oblikovanje važećih odredbi, ostale kvalifikacije - koje se na odgovarajući način primjenjuju i na suce porotnike, poput odredbe o zabrani obavljanja službe ili posla "koji bi mogli utjecati na njegovu samostalnost, nepristranost ili neovisnost" ili dovesti do umanjenja njegova društvenog ugleda ili su inače inkompatibilni s obnašanjem sudačke dužnosti - izrijekom su uređene tek Zakonom o sudovima iz 1994. Iako se razlozi nespojivosti dužnosti za građane laike spominju i mnogo ranije, i to u propisima iz 1849. i 1875., s obzirom na vremenski raspon, a posebice normativni izričaj s taksativno navedenim dužnostima, tj. službama koje su se nekoć smatrale nespojivima s porotničkom dužnošću, teško bi se moglo govoriti o nekom zbiljskom utjecaju tih propisa iz 19. stoljeća na važeća zakonska rješenja. Što se tiče mogućnosti unaprjeđenja važećih rješenja koja se tiču potonjih kvalifikacija, u radu je istaknuto da bi zbog pojedinih primjera iz prakse umjesto formulacije o odgovarajućoj primjeni zakonskih odredbi koje se odnose na suce izrijekom valjalo navesti kvalifikacije iz članka 90. stavka 1. i članka 91. stavaka 2. i 3. Zakona o sudovima, uključujući i kvalifikaciju iz članka 120. stavka 2. podstavka 5. Ustava Republike Hrvatske o gornjoj dobnoj granici od 70 godina života. 
Polazeći od shvaćanja da je kod suđenja maloljetniku nužno iznaći najpogodnije rješenje u okviru zakona, u cilju ispravnog usmjeravanja njegova daljnjeg razvoja, zakonodavac je uz sve prethodno spomenute kvalifikacije predvidio i dodatne, najprije općenito zahtijevajući iskustvo u odgoju djece (1948.), a zatim i dodajući da se mora raditi o profesorima, učiteljima, odgajateljima ili drugim osobama s iskustvom u odgoju maloljetnika (1953.). Otada pa sve do 2011. navedena kvalifikacija preuzimana je u gotovo neizmijenjenom obliku, s time da je od 2011. pojam iskustva preciziran tako da se zahtijeva radno iskustvo, i to ne više u odgoju, nego u stručnom odgojnom radu s mladim osobama, što je formulacija koja je na snazi i danas. Međutim, zakonodavac nije pobliže odredio razdoblje tog iskustva i način utvrđivanja te kvalifikacije, iako primjeri iz prakse i ovdje otkrivaju prostor za stanovita unaprjeđenja dopunom važećih rješenja, primjerice, u okviru članka 41. Zakona o sudovima za mladež, i to propisivanjem minimalnog broja godina radnog iskustva u stručnom odgojnom radu s mladim osobama (npr. najmanje pet godina), kao i obveze kandidata da već pri podnošenju prijave dostave dokaz o radnom iskustvu u struci.

Mnogo dinamičnije bilo je oblikovanje kvalifikacija za suce porotnike vojnih sudova, koje su, s obzirom na posebnu narav tih sudova, redovito bile vezane uz određeni status, odnosno čin. Najprije su suci porotnici (kao tzv. vojni prisuditelji) morali biti iz redova generala, admirala, oficira, podoficira i boraca (1945.), zatim su kao tzv. suci morali biti iz redova oficira, ali i drugih redova vojske i struka, uz uvjet da svoju sudačku dužnost obnašaju uz redovnu dužnost u vojsci (1946.), dok su pod nazivom sudaca porotnika morali biti iz redova oficira i podoficira, pri čemu su sudačku dužnost morali obnašati uz svoju redovnu dužnost (1947.). Potom se opet zahtijevalo da budu iz reda generala, admirala, oficira, vojnih službenika i podoficira, uz uvjet navršenih 27 godina (1954.), nakon čega se odustalo od zahtijeva za činom generala i admirala te uvjeta od 27 godina (1965.) da bi se, potom, proširio krug na oficire, mlađe oficire, vojne službenike, ali i građanske osobe na službi u oružnim snagama (1977.), što je ostalo na snazi do 1991. Za razliku od dotadašnjih rješenja, koja su počivala na uređenju na zakonskoj razini, do 2013. kvalifikacije za suca porotnika u vojnostegovnim sudovima bile su uređene na podzakonskoj razini, uz zahtjev da sudac porotnik mora biti jednakog ili višega osobnog čina od osobnog čina okrivljenika, dok se važećim Zakonom o službi u Oružanim snagama Republike Hrvatske traži čin generala/admirala što bi djelomice (uz izuzetak nižih činova) odgovaralo zakonskim rješenjima iz 1945. i 1954.

Iz svega dosad izloženog valjalo bi zaključiti kako je u oblikovanju važećih odredbi koje uređuju materiju kvalifikacija za participaciju građana laika u prisjedničkom suđenju kao sudaca porotnika vidljiv utjecaj ranijih zakonskih rješenja, napose iz razdoblja od 1945. do 1954., ali i da postoji prostor za unaprjeđenje pojedinih važećih rješenja. Usto, oblikovanje važećih zakonskih rješenja imalo je vrlo dinamičan razvoj, posebice kada je riječ kvalifikacijama za suce porotnike vojnih sudova, s brojnim izmjenama propisa koji su ih uređivali, izuzimajući kvalifikacije kod suđenja mladim osobama koje nisu mijenjane nešto više od pola stoljeća. Naposljetku, imajući u vidu da se u izloženim propisima zahtijeva relativno mali broj kvalifikacija za participaciju građana laika, zaključno valja primijetiti i kako je zakonodavac takvim normativnim pristupom omogućio participaciju vrlo širokoga kruga građana čime bi se, uz tek manje dopune važećih zakonskih rješenja koje se ističu u ovom radu, mogao stvoriti solidan normativni okvir koji omogućuje oživotvorenje izloženih značajnih uloga participacije i predstavlja zbiljski poticajno okruženje za sudjelovanje građana u postupcima donošenja odluka. Iako se u ovom istraživanju nisu ispitivala pojedina rješenja iz usporednog prava i prakse, kao i neka druga povezana pitanja, poput učinaka participacije građana laika u suđenju, s obzirom na to 
da bi se time premašio opseg i postavljeni cilj ovog rada, u perspektivi budućih istraživanja iste materije valjalo bi pobliže razmotriti i te dimenzije kvalifikacija koje bi eventualno mogle ukazati na mogućnost njihova daljnjega normativnog unaprjeđenja.

\section{LITERATURA}

1. Antal, T., The Codification of the Jury Procedure in Hungary, The Journal of Legal History, god. 30, br. 3, 2009., str. 279.-297.

2. Aristotel, Politika, Globus-Sveučilišna naklada Liber, Zagreb, 1988.

3. Assemblée Nationale, La Constitution française, Présentée au Roi par l' Assemblée Nationale, le 3 septembre 1791, Imprimerie de Prudhomme, Paris, 1791.

4. Bablitz, L., Actors and Audience in the Roman Courtroom, Routledge, Abingdon-New York, 2007.

5. Bačić, A., Ustavno pravo i političke institucije: studijski izvori, Pravni fakultet, Split, 2012.

6. Badami, N.; Chandu, M., Access to Justice in India, u: M. Schmiegelow; H. Schmiegelow (ur.), Institutional Competition between Common Law and Civil Law: Theory and Policy, Springer, Berlin-Heidelberg, 2014., str. 211.-235.

7. Baldwin, S. E., French Jury System, Michigan Law Review, god. 2, br. 7, 1904., str. 597.-600.

8. Bayer, V., Problem sudjelovanja nepravnika u savremenom kaznenom sudovanju, Tiskara Merkantile (Jutriša i Sedmak), Zagreb, 1940.

9. Bayer, V., Suci porotnici, Zbornik Pravnog fakulteta u Zagrebu, god. 5, br. 3-4, 1955., str. 142.-156.

10. Borković, I., Postupak i tehnika izrade pravnih propisa, Informator, Zagreb, 1987.

11. Casper, G.; Zeisel, H., Lay judges in the German criminal courts, The Journal of Legal Studies, god. 1, br. 1, 1972., str. 135.-191.

12. Chroust, A.-H.; Murphy, J. R., Lex Acilia and the Rise of Trial by Jury in the Roman World, Notre Dame Law Review, god. 24, br. 1, 1948., str. 1.-40.

13. Čepulo, D., Izgradnja modernog hrvatskog sudstva 1848-1918., Zbornik Pravnog fakulteta u Zagrebu, god. 56, br. 2-3, 2006., str. 325.-383.

14. Čepulo, D., Sloboda tiska i porotno suđenje u banskoj Hrvatskoj 1848-1918., Hrvatski ljetopis za kazneno pravo i praksu, god. 7, br. 2, 2000., str. 923.-975.

15. Čulinović, F., Porota u Jugoslaviji, Zbornik Pravnog fakulteta u Zagrebu, god. 4, br. 1-2, 1954., str. 40.-58.

16. Damjanović, S.; Jurčević, I.; Kuštović, T.; Kuzmić, B.; Lukić, M.; Žagar, M., Mali staroslavensko-hrvatski rječnik, Matica hrvatska, Zagreb, 2004.

17. Dubber, M.; Pihlajamäki, H., Lay participation in modern law: a comparative historical analysis, Comparative Legal History, god. 3, br. 2, 2015., str. 224.-230.

18. Carette, A. A., Lois annotées ou Lois, décrets, ordonnances, avis du conseil d'état, Pouleur, Paris, 1843.

19. Erent-Sunko, Z., Atenske demokratske institucije i njihov odraz na socijalne pojave (6.-4. st. pr. n. e.), Pravni fakultet Sveučilišta u Zagrebu, Zagreb, 2007.

20. Forsyth, W., History of trial by jury, R. Carswell, Toronto, 1876.

21. Freie, J. F., Participatory democracy, u: D. Levinson; K. Christensen (ur.), Encyclopedia of Community: From the Village to the Virtual World, Volume 1, Sage Publications, Thousand Oaks-London, 2003., str. 162. 
22. Hans, V. P., American Juries: The Verdict, Prometheus Books, New York, 2007.

23. Hans, V. P., Introduction: Lay Participation in Legal Decision Making, Law and Policy, god 25, br. 2, 2003., str. 83.-92.

24. Horvat, M., Rimsko pravo, Pravni fakultet Sveučilišta u Zagrebu, Zagreb, 2007.

25. Jaffe, J., After Nanavati The Last Jury Trial in India?, Economic \& Political Weekly, god. 52, br. 32, 2017., str. 18.-20.

26. Jimeno-Bulnes, M., A Different Story Line for 12 Angry Men: Verdicts Reached by Majority Rule - The Spanish Perspective, Chicago-Kent Law Review, god. 82, br. 2, 2007., str. 759.-775.

27. Jimeno-Bulnes, M.; Hans, V. P., Legal Interpreter for the Jury: The Role of the Clerk of the Court in Spain, Onati Socio-legal Series, god. 6, br. 2, 2016., str. 197.-215.

28. Jonakait, R. N., The American jury system, Yale University Press, New Haven, 2003.

29. Jovanović, M., Porota u pravosuđu Jugoslavije, Savremena administracija, Beograd, 1958.

30. Kamhi, S.; Čalija. B., Sistem porote u našoj zemlji i problemi vezani za učešće građana u vršenju pravosuđa, Svjetlost, Sarajevo, 1974.

31. Koprić, I.; Manojlović, R., Participacija građana u lokalnoj samoupravi - nova hrvatska pravna regulacija i neka komparativna iskustva, u: B. Davitkovski (ur.), Četvrti Skopsko-zagrebački pravni kolokvij, Pravni fakultet, Skopje, 2013., str. 9.-35.

32. Krapac, D.; Đurđević, Z.; Ivičević Karas, E.; Bonačić, M.; Burić, Z., Kazneno procesno pravo, Prva knjiga: Institucije, Narodne novine, Zagreb, 2015.

33. Kutnjak Ivković, S., Exploring Lay Participation in Legal Decision-Making: Lessons from Mixed Tribunals, Cornell International Law Journal, god. 40, br. 2, 2007., str. 429.-453.

34. Kużelewski, D., The Election of Lay Judges and the Principle of Participation by Citizenry in the Administration of Criminal Justice, Białostockie Studia Prawnicze, god. 20/A, 2016., str. 143.-152.

35. Leib, E. J., A Comparison of Criminal Jury Decision Rules in Democratic Countries, Ohio State Journal of Criminal Law, god. 5, 2008., str. 629.-644.

36. Ljubanović, V., Demokratizacija krivičnog pravosuđa, Pravni fakultet Sveučilišta u Osijeku, Osijek, 1989.

37. Machura, S., Civil Justice: Lay Judges in the EU Countries, Onati Socio-legal Series, god. 6, br. 2, 2016. , str. 235.-254.

38. Machura, S., Interaction between lay assessors and professional judges in German mixed courts, Revue internationale de droit pénal, god. 72, br. 1-2, 2001., str. 451.-479.

39. MacKercher, J., Trial by jury, [s. n.], Montreal, 1891.

40. Malsch, M., Democracy in the Courts: Lay Participation in European Criminal Justice Systems, Ashgate, Surrey, 2009.

41. Margetić, L., Vinodolski zakon, Adamić-Nakladni zavod Globus, Rijeka-Zagreb, 2008.

42. Masschaele, J., Jury, state, and society in medieval England, Palgrave Macmillan, New York, 2008.

43. Mažuranić, V., Prinosi za hrvatski pravno-povjestni rječnik. Svezak I., Knjižarnica Jugoslavenske akademije (dioničke tiskare) (Gjuro Trpinac), Zagreb, 1908.

44. Michels, A. M. B., Citizen participation and democracy in the Netherlands, Democratization, god. 13, br. 2, 2006., str. 323.-339.

45. Oshisanya, O., An Almanac of Contemporary and Comparative Judicial Restatements (ACCJR) Supplement II: Public Law, Almanac Foundation, Lagos, 2016.

46. Pastović, D., Analiza prakse porotnog suda u Rovinju 1874.-1918., Zagrebačka pravna revija, god. 4, br. 1, 2015., str. 11.-39. 
47. Pastović, D., Sloboda tiska i porotna sudbenost u Istri 1848./1849., Zbornik Pravnog fakulteta Sveučilišta u Rijeci, god. 36, br. 2, 2015., str. 722.-758.

48. Pateman, C., Participatory democracy revisited, Perspectives on Politics, god. 10, br. 1, 2012., str. 7.-19.

49. Pavičić, A., Sudjelovanje sudaca porotnika u kaznenim postupcima pred Županijskim sudom u Zagrebu, Hrvatski ljetopis za kazneno pravo i praksu, god. 12, br. 1, 2005., str. 63.-85.

50. Phillips, A., (O)rađanje demokracije, Ženska infoteka, Zagreb, 2001.

51. Pieterse, J. N., Participatory democratization reconceived, Futures, god. 33, br. 5, 2001., str. 407.-422.

52. Proffatt, J., Treatise on Trial by Jury: Including Question of Law and Fact With an Introductory Chapter on the Origin and History of Jury Trial, Sumner Whitney and Company, San Francisco, 1880.

53. Radman, Z., Građanstvo i javne politike: Utjecaj različitih modela građanstva na rezultate politike upravljanja prostorom u jadranskim regijama, Politička kultura, Zagreb, 2010.

54. Ravlić, S., Demokracija u globaliziranom svijetu, u: A. Milardović; N. Jožanc (ur.), Demokracija i postdemokracija, Pan liber, Zagreb, 2013., str. 171.-191.

55. Repp, T. G., A historical treatise on trial by jury, wager of law, and other co-ordinate forensic institutions, formerly in use in Scandinavia and Iceland, Saunders and Benning, London, 1832.

56. Smičiklas, T., Codex diplomaticus regni Croatiae, Dalmatiae et Slavoniae. Volumen II. Diplomata saeculi XII. Continens - Diplomatički zbornik Kraljevine Hrvatske, Dalmacije i Slavonije. Svezak 2. Listine XII. vijeka (1101-1200), Tisak dioničke tiskare, Zagreb, 1904.

57. Stevanović, Č., Neka pitanja u vezi sa učešćem građana u suđenju, Zbornik radova Pravnog fakulteta u Nišu, [s. n.], br. 15, 1975., str. 65.-78.

58. Struić, G., Vjerodostojno tumačenje zakona u hrvatskom parlamentarnom pravu od 1947. do danas, Hrvatska i komparativna javna uprava, god. 16, br. 3, 2016., str. 553.-585.

59. Struić, G.; Bratić, V., Public participation in the budgetary process in the Republic of Croatia, Public Sector Economics, god. 42, br. 1, 2018., str. 67.-92.

60. Struić, G.; Bratić, V., Sudjelovanje javnosti u zakonodavnom postupku: primjer Odbora za financije $i$ državni proračun Hrvatskoga sabora, Hrvatska i komparativna javna uprava, god. 17, br. 1, 2017. str. 131.-152.

61. Šulek, B., Izabrani članci, Jugoslavenska akademija znanosti i umjetnosti, Zagreb, 1952.

62. Thaman, S. C., Europe's New Jury Systems: The Cases of Spain and Russia, Law and Contemporary Problems, god. 62, br. 2, 1999., str. 233.-259.

63. Thaman, S. C., The Nullification of the Russian Jury: Lessons for Jury-Inspired Reform in Eurasia and beyond, Cornell International Law Journal, god. 40, br. 2, 2007., str. 355.-428.

64. Tocqueville, A. de, O demokraciji u Americi, Informator-Fakultet političkih znanosti, Zagreb, 1995.

65. Triva, S.; Dika, M., Građansko parnično procesno pravo, Narodne novine, Zagreb, 2004.

66. Vidačak, I.; Đurman, P., Savjetovanje s javnošću u donošenju propisa: kvaliteta javnog odlučivanja i sudjelovanje građana, u: I. Koprić; A. Musa; T. Giljević, (ur.), Građani, javna uprava, lokalna samouprava: povjerenje, suradnja, potpora, Institut za javnu upravu, Zagreb, 2017., str. 73.-104.

67. Vidmar, N. (ur.), World Jury Systems, Oxford University Press, New York, 2000.

68. Vidmar, N.; Abbott, W. F.; Batt, J. (ur.), A handbook of jury research, American Law Institute-American Bar Association, Philadelphia, 1999.

69. Zuglia, S., Sudovi i ostali organi koji učestvuju u vršenju građanskog pravosuđa, Školska knjiga, Zagreb, 1956. 


\section{POPIS PROPISA I AKATA}

1. Jedinstvena metodološko-nomotehnička pravila za izradu akata koje donosi Hrvatski sabor, Narodne novine, broj 74/2015.

2. Kazneni postupnik, Dèržavo-zakonski list za kraljevine i zemlje, zastupane u vieću cesarevinskom. Godina 1873., Iz c. kr. dèržavne i dvorske štamparije, Beč, 1873.

3. Kodeks savjetovanja sa zainteresiranom javnošću u postupcima donošenja zakona, drugih propisa i akata, Narodne novine, broj 140/2009.

4. Odluka Ustavnog suda Republike Hrvatske broj: U-III-706/2003 od 8. srpnja 2003., Narodne novine, broj 120/2003.

5. Osnovni zakon o sudovima opće nadležnosti, Službeni list Socijalističke Federativne Republike Jugoslavije, broj 7/1965.

6. Poslovnik Hrvatskoga sabora, Narodne novine, broj 81/2013, 113/2016, 69/2017, 29/2018.

7. Pravilnik o pomorskoj arbitraži pri Trgovinskoj komori FNRJ, Službeni list Federativne Narodne Republike Jugoslavije, broj 26/1947.

8. Pravilnik o vanjsko-trgovinskoj arbitraži pri Trgovinskoj komori FNRJ, Službeni list Federativne Narodne Republike Jugoslavije, broj 26/1947.

9. Pravilnik o vojnoj stezi (2003.), Narodne novine, broj 95/2003.

10. Pravilnik o vojnoj stezi (2008.), Narodne novine, broj 3/2008.

11. Rješenje Ustavnog suda Republike Hrvatske broj: U-I-337/1994 od 5. srpnja 1995., Narodne novine, broj 49/1995.

12. Rješenje Ustavnog suda Republike Hrvatske broj: U-I-1080/2002 i dr. od 12. ožujka 2008., Narodne novine, broj 50/2008.

13. Uredba o počasnim sudijama, Službene novine Kraljevine Jugoslavije od 3. kolovoza 1933., broj 174-XLIX.

14. Ustav Federativne Narodne Republike Jugoslavije, Službeni list Federativne Narodne Republike Jugoslavije, broj 10/1946.

15. Ustav Kraljevine Srba, Hrvata i Slovenaca od 28. lipnja 1921., Službene novine Kraljevine Srba, Hrvata i Slovenaca od 28. lipnja 1921., broj 142A.

16. Ustav Narodne Republike Hrvatske, Narodne novine, broj 7/1947.

17. Ustav Republike Hrvatske, Narodne novine, broj 56/1990, 135/1997, 8/1998, 113/2000, 124/2000, 28/2001, 41/2001, 55/2001, 76/2010, 85/2010, 5/2014.

18. Ustav Socijalističke Federativne Republike Jugoslavije (1963.), Službeni list Socijalističke Federativne Republike Jugoslavije, broj 14/1963.

19. Ustav Socijalističke Federativne Republike Jugoslavije (1974.), Službeni list Socijalističke Federativne Republike Jugoslavije, broj 9/1974.

20. Ustav Socijalističke Republike Hrvatske (1963.), Narodne novine, broj 15/1963.

21. Ustav Socijalističke Republike Hrvatske (1974.), Narodne novine, broj 8/1974.

22. Ustavni zakon Narodne Republike Hrvatske o osnovama društvenog i političkog uređenja i republičkim organima vlasti, Narodne novine, broj 9/1953.

23. Ustavni zakon o pravima nacionalnih manjina, Narodne novine, broj 155/2002, 47/2010, 80/2010, 93/2011, 93/2011. 
24. Ustavni zakon o osnovama društvenog i političkog uređenja Federativne Narodne Republike Jugoslavije i saveznim organima vlasti, Službeni list Federativne Narodne Republike Jugoslavije, broj 3/1953.

25. Zakon o arbitraži, Narodne novine, broj 88/2001.

26. Zakon o biračkim spiskovima, Službeni list Demokratske Federativne Jugoslavije, broj 59/1945.

27. Zakon o Državnom sudbenom vijeću, Narodne novine, broj 116/2010, 57/2011, 130/2011, 13/2013, 28/2013, 82/2015, 67/2018.

28. Zakon o kaznenom postupku, Narodne novine, broj 110/1997.

29. Zakon o krivičnom postupku (1948.), Službeni list Federativne Narodne Republike Jugoslavije, broj 97/1948.

30. Zakon o krivičnom postupku (1977.), Službeni list Socijalističke Federativne Republike Jugoslavije, broj 4/1977.

31. Zakon o mirovnim vijećima, Narodne novine, broj 14/1978.

32. Zakon o poroti, Srpske novine, broj 134/1871.

33. Zakon o pravu na pristup informacijama, Narodne novine, broj 25/2013, 85/2015.

34. Zakon o prestanku rada sudova udruženog rada, Narodne novine, broj 53/1990.

35. Zakon o privrednim sudovima (1954.), Službeni list Federativne Narodne Republike Jugoslavije, broj 31/1954.

36. Zakon o privrednim sudovima (1965.), Službeni list Socijalističke Federativne Republike Jugoslavije, broj 7/1965.

37. Zakon o procjeni učinaka propisa, Narodne novine, broj 44/2017.

38. Zakon o ravnopravnosti spolova, Narodne novine, broj 82/2008,138/2012, 69/2017.

39. Zakon o redovnim sudovima, Narodne novine, broj 5/1977, 17/1987, 27/1988, 16/1990, 41/1990, 14/1991.

40. Zakon o Saveznom sudu, Službeni list Socijalističke Federativne Republike Jugoslavije, broj 21/1974, 4/1977, 20/1982, 20/1990.

41. Zakon o službi u oružanim snagama Republike Hrvatske (2002.), Narodne novine, broj 33/2002, 58/2002, 175/2003, 136/2004, 76/2007, 88/2009, 124/2009, 73/2013.

42. Zakon o službi u oružanim snagama Republike Hrvatske (2013.), Narodne novine, broj 73/2013, 75/2015, 50/2016, 30/2018.

43. Zakon o stavljanju izvan snage u Republici Hrvatskoj Zakona o pomilovanju, Zakona o Saveznom sudu, Zakona o sudovima udruženog rada, Zakona o Saveznom javnom pravobranilaštvu, Zakona o postupku za upis u sudski registar, Zakona o saveznim sudskim taksama, Zakona o društvenom pravobraniocu samoupravljanja i Zakona o Saveznom društvenom pravobraniocu samoupravljanja, Narodne novine, broj 53/1991.

44. Zakon o stavljanju izvan snage u Republici Hrvatskoj Zakona o vojnim sudovima i Zakona o vojnom tužilaštvu, Narodne novine, broj 53/1991.

45. Zakon o sudovima, Službeni list Federativne Narodne Republike Jugoslavije, broj 30/1954.

46. Zakon o sudovima (1967.), Narodne novine, broj 21/1967.

47. Zakon o sudovima (1994.), Narodne novine, broj 3/1994, 100/1996, 115/1997, 131/1997, 129/2000, 67/2001, 5/2002, 101/2003, 17/2004, 141/2004, 150/2005.

48. Zakon o sudovima (2005.), Narodne novine, broj 150/2005, 16/2007, 113/2008, 153/2009, 34/2010, 116/2010, 27/2011, 57/2011, 130/2011, 28/2013. 
49. Zakon o sudovima (2013.), Narodne novine, broj 28/2013, 33/2015, 82/2015, 82/2016, 67/2018.

50. Zakon o sudovima udruženog rada, Narodne novine, broj 26/1976, 31/1977, 25/1980, 27/1987, 27/1988, 33/1988.

51. Zakon o sudovima udruženog rada (1974.), Službeni list Socijalističke Federativne Republike Jugoslavije, broj 24/1974.

52. Zakon o sudovima udruženog rada (1984.), Službeni list Socijalističke Federativne Republike Jugoslavije, broj 38/1984, 57/1989.

53. Zakon o sudovima za mladež (1997.), Narodne novine, broj 111/1997, 27/1998, 12/2002, 84/2011.

54. Zakon o sudovima za mladež (2011.), Narodne novine, broj 84/2011, 143/2012, 148/2013, $56 / 2015$.

55. Zakon o uređenju i nadležnosti vojnih sudova u Jugoslavenskoj armiji, Službeni list Demokratske Federativne Jugoslavije, broj 65/1945, 58/1946.

56. Zakon o uređenju i postupku sudova socijalnog osiguranja, Službeni list Federativne Narodne Republike Jugoslavije, broj 83/1946.

57. Zakon o uređenju narodnih sudova, Službeni list Demokratske Federativne Jugoslavije, broj 67/1945, 51/1946.

58. Zakon o uređenju redovnih sudova za Kraljevinu Srba, Hrvata i Slovenaca od 18. siječnja 1929., Službene novine Kraljevine Srba, Hrvata i Slovenaca od 25. siječnja 1929., broj 20-X.

59. Zakon o vojnim sudovima (1947.), Službeni list Demokratske Federativne Jugoslavije, broj 105/1947.

60. Zakon o vojnim sudovima (1954.), Službeni list Federativne Narodne Republike Jugoslavije, broj $52 / 1954$.

61. Zakon o vojnim sudovima (1965.), Službeni list Socijalističke Federativne Republike Jugoslavije, broj 7/1965.

62. Zakon o vojnim sudovima (1977.), Službeni list Socijalističke Federativne Republike Jugoslavije, broj 4/1977, 23/1977, 13/1982.

63. Zakon od 6. srpnja 1888. kojim se preinačuju i nadopunjuju neke ustanove zakona od 17. svibnja 1875. o kaznenom postupku (sbornik zakonah i naredabah br. 30, god. 1875), Sbornik zakonah i naredabah valjanih za kraljevinu Hrvatsku i Slavoniju. Godina 1888. (Komad I.-XVIII. Br. 1.-79.), Tiskarski zavod “Narodnih Novinah”, Zagreb, 1888.

64. Zakon od 17. svibnja 1875. o kaznenom postupku, Sbornik zakonah i naredabah valjanih za kraljevinu Hrvatsku i Slavoniju. Godina 1875. (Komad I.-XXXIX. Br. 1.-88.), Brzotiskom tiskare "Narodnih Novinah", Zagreb, 1876.

65. Zakon od 17. svibnja 1875. o kaznenom postupku u poslovih tiskovnih za kraljevine Hrvatsku i Slavoniju, Sbornik zakona i naredabah valjanih za kraljevinu Hrvatsku i Slavoniju. Godina 1875. (Komad I.-XXXIX. Br. 1.-88.), Brzotiskom tiskare "Narodnih Novinah", Zagreb, 1876.

66. Zakon od 17. svibnja 1875. o propisu, kako se imadu sastavljati porotnički imenici za sudove tiskovne u kraljevini Hrvatskoj i Slavoniji, Sbornik zakona i naredabah valjanih za kraljevinu Hrvatsku i Slavoniju. Godina 1875. (Komad I.-XXXIX. Br. 1.-88.), Brzotiskom tiskare "Narodnih Novinah", Zagreb, 1876.

67. Zakon od 23. Svibnja 1873, kojim se uvodi postupnik kazneni, Dèržavo-zakonski list za kraljevine i zemlje, zastupane u vieću cesarevinskom. Godina 1873., Iz c. kr. dèržavne i dvorske štamparije, Beč, 1873.

68. Zakon od 23. Svibnja 1873, o tom, kako se sastavljaju imenici porotnikah, Dèržavo-zakonski list za kraljevine i zemlje, zastupane u vieću cesarevinskom. Godina 1873., Iz c. kr. dèržavne i dvorske štamparije, Beč, 1873. 
69. Zakonik o krivičnom postupku, Službeni list Federativne Narodne Republike Jugoslavije, broj 40/1953, 52/1959, 30/1962 i Službeni list Socijalističke Federativne Republike Jugoslavije, broj 12/1965, 23/1967.

70. Zakonik o sudskom krivičnom postupku za Kraljevinu Srba, Hrvata i Slovenaca od 16. veljače 1929., Službene novine Kraljevine Srba, Hrvata i Slovenaca od 23. veljače 1929., broj 45-XX.

\section{MREŽNI IZVORI}

1. [s. n.] Grad Gospić traži kandidate za suce porotnike Općinskog suda u Gospiću. URL=http://gospic.hr/ file/2018/09/Izjava-suci-porotnici.docx. Pristupljeno 10. ožujka 2019.

2. [s. n.] Javni poziv - prijedlog za imenovanje sudaca porotnika Županijskog suda u Sisku i sudaca porotnika za mladež Županijskog suda u Sisku. URL=http://novska.hr/hr/on-line-vijesti/javni-poziv---prijedlog-za-imenovanje-sudaca-porotnika-zupaniskog-suda,4589.html. Pristupljeno 10. ožujka 2019.

3. [s. n.] Prijave za imenovanje sudaca porotnika. URL=http://www.gorica.hr/dokumenti/izjava-porotnici.doc. Pristupljeno 10. ožujka 2019.

4. [s. n.] Sude nam političari s kaznenim prijavama. URL=https://www.jutarnji.hr/arhiva/sude-nam-politicari-s-kaznenim-prijavama-nije-uslo/4008990/amp. Pristupljeno 10. ožujka 2019.

5. [s. n.] Šeks opet odbio suce porotnike. URL=https://www.jutarnji.hr/arhiva/seks-opet-odbio-suce-porotnike/3389516/. Pristupljeno 10. ožujka 2019.

6. Odluka Ustavnog suda Republike Hrvatske broj: U-III-2916/2007 od 16. listopada 2012. URL=https://www.usud.hr./. Pristupljeno 10. ožujka 2019.

7. Prijedlog zaključka o utvrđivanju prijedloga za imenovanje sudaca porotnika Općinskog suda u Splitu. URL=http://www.split.hr/lgs.axd?t=16\&id=22693. Pristupljeno 10. ožujka 2019.

8. Strižić, Z; Jurasić, D., Bludničio nad djetetom, a i dalje je u vijeću koje sudi zlostavljačima. URL=https:// www.vecernji.hr/vijesti/bludnicio-nad-djetetom-a-i-dalje-je-u-vijecu-koje-sudi-zlostavljacima-239586. Pristupljeno 10. ožujka 2019.

9. Urukalo, V., Suci se žale: Porotnici su amateri koji nas mogu preglasati. URL=https://www.slobodnadalmacija.hr/novosti/hrvatska/clanak/id/311715/suci-se-zale-porotnici-su-amateri-koji-nas-mogu-preglasati. Pristupljeno 10. ožujka 2019.

10. Ustav Ruske Sovjetske Federativne Socijalističke Republike (Конституция Российской Советской Федеративной Социалистической Республики). URL=http://constitution.garant.ru/history/ussrrsfsr/1937/. Pristupljeno 10. ožujka 2019.

11. Ustav Saveza Sovjetskih Socijalističkih Republika (Конституция Союза Советских Социалистических Республик). URL=http://constitution.garant.ru/history/ussr-rsfsr/1936/. Pristupljeno 10. ožujka 2019.

12. Zaključak o pokretanju postupka za imenovanje sudaca porotnika Općinskog suda u Osijeku. URL=http://opcina-vladislavci.hr/wp-content/uploads/2018/09/Imenovanje-sudaca-porotnika-Opcinskog-suda-u-Osijeku.pdf. Pristupljeno: 10. ožujka 2019.

13. Zaključak o utvrđivanju prijedloga kandidata za imenovanje sudaca porotnika Županijskog suda u Varaždinu. URL=http://www.medjimurska-zupanija.hr/images/sjednice-skupstine-2013/3/25.pdf. Pristupljeno: 10. ožujka 2019. 
Gordan Struić*

\section{LEGAL REGULATION OF REQUIREMENTS FOR LAY PARTICIPATION IN A TRIAL IN CROATIA FROM 1848 TO 2018}

\section{Summary}

Starting from the fact that the participation of citizens in the decision-making process is not only realized in the legislative and executive, but also in the judicial power, this paper discusses the requirements (that is, qualifications) for lay participation in a trial. The introduction of particular requirements, and particularly their increased number, significantly can influence the ability of lay citizens to participate in a trial, limiting the number of those who can meet these requirements and reducing the ability to materialize important role of participation that does not only contain the vital imperative in the contemporary constitutional democratic state for democratization of the judiciary, but also an important educational and integrative component. Having in mind the fact that in some periods of Croatian history lay citizens participated as jurors in a jury trial and then as lay judges in mixed tribunals, in the effort for a complete and systematic approach to this matter, the paper examines relevant regulations and available literature on the legal regulation of requirements for lay participation in a trial in Croatia in the period from 1848 to 2018 to explore the possible impact of previous regulations on this matter on the existing regulation, as well as the possible improvement of the latter.

Keywords: $\quad$ participation, lay citizens, mixed tribunal, jury trial

\section{(c) (1) (\$)}

This work is licensed under a Creative Commons

Attribution-NonCommercial 4.0 International License.

\footnotetext{
* Gordan Struić, master of laws and university specialist in comparative politics, Croatian Parliament, Trg svetoga Marka 6, 10000 Zagreb, Republic of Croatia. Email address: gordan.struic@gmail.com. ORCID: http://orcid.org/0000-0001-6528-4436. The views expressed here are solely those of the author.
} 